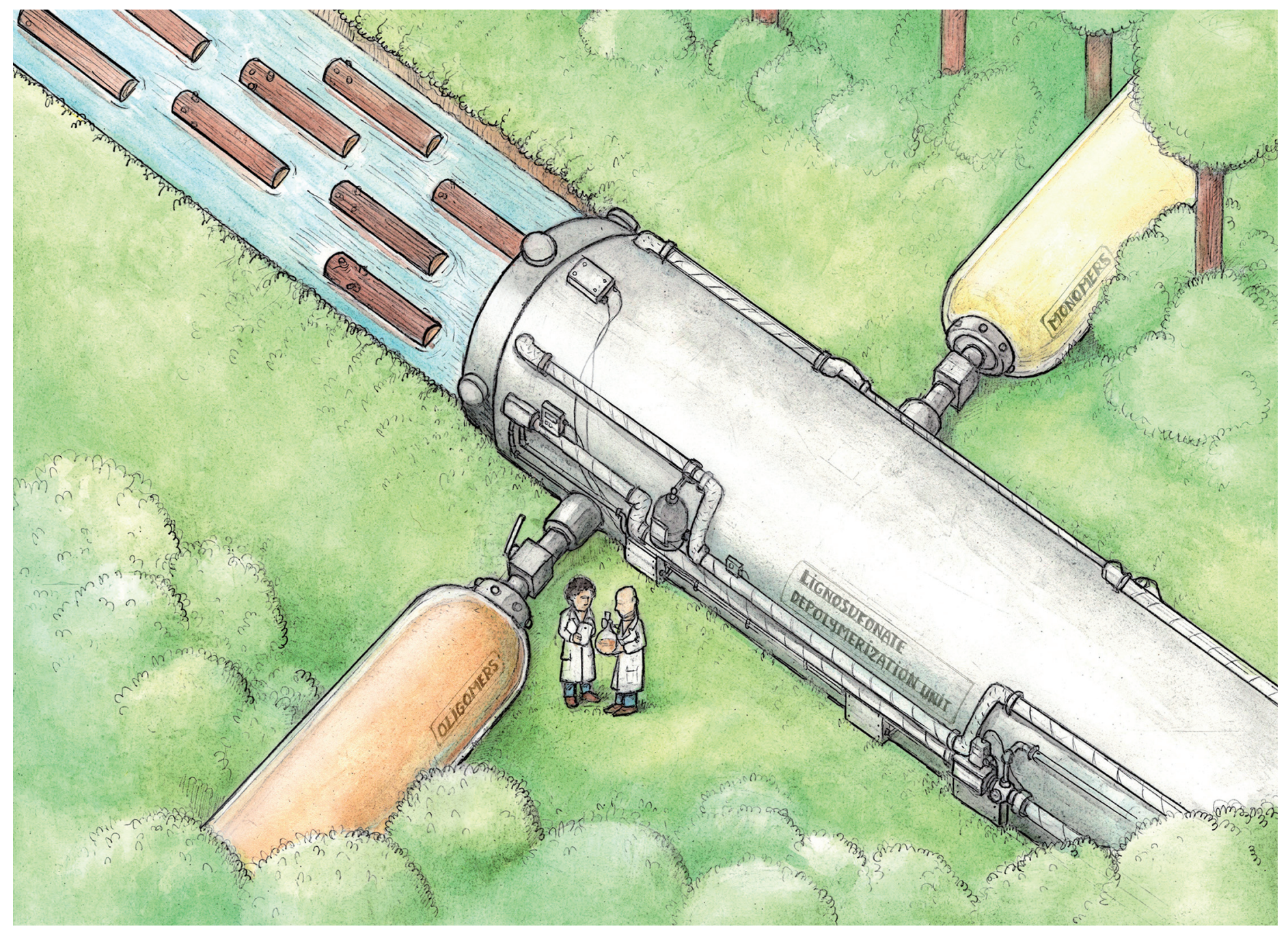

An article presented by the group of Dr. Majd Al-Naji from the Max Planck Institute of Colloids and Interfaces (Germany).

Controlled lignosulfonate depolymerization via solvothermal fragmentation coupled with catalytic hydrogenolysis/ hydrogenation in a continuous flow reactor

Sodium lignosulfonate as a side stream product from the pulp industry was valorized in a continuous flow system using solvothermal fragmentation independently, as well as combined with a catalytic hydrogenolysis/hydrogenation step. Using this simple and tunable process, sodium lignosulfonate was simultaneously deconstructed towards high monomer yields or low molecular weight oligomers. Thus, this approach can potentially be applied for the production of both fine chemicals and smart materials.

\section{As featured in:}

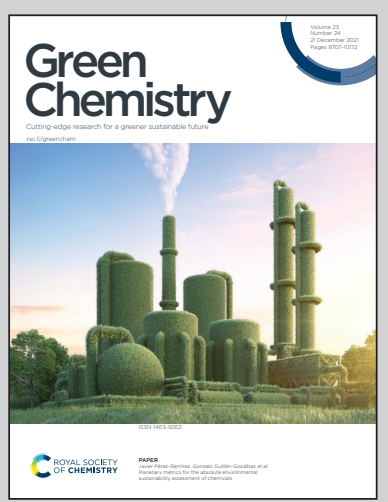

See Majd Al-Naji et al., Green Chem., 2021, 23, 9894. 


\section{(A) Check for updates}

Cite this: Green Chem., 2021, 23 9894

\title{
Controlled lignosulfonate depolymerization via solvothermal fragmentation coupled with catalytic hydrogenolysis/hydrogenation in a continuous flow reactor $\dagger$
}

\begin{abstract}
Francesco Brandi, (D) Markus Antonietti (D) and Majd Al-Naji (D)*
Sodium lignosulfonate (LS) was valorized to low molecular weight $\left(M_{w}\right)$ fractions by combining solvothermal (SF) and catalytic hydrogenolysis/hydrogenation fragmentation (SHF) in a continuous flow system. This was achieved in either alcohol/ $\mathrm{H}_{2} \mathrm{O}\left(\mathrm{EtOH} / \mathrm{H}_{2} \mathrm{O}\right.$ or $\left.\mathrm{MeOH} / \mathrm{H}_{2} \mathrm{O}\right)$ or $\mathrm{H}_{2} \mathrm{O}$ as a solvent and Ni on nitrogen-doped carbon as a catalyst. The tunability according to the temperature of both SF and catalytic SHF of LS has been separately investigated at $150{ }^{\circ} \mathrm{C}, 200{ }^{\circ} \mathrm{C}$, and $250{ }^{\circ} \mathrm{C}$. In SF, the minimal $\mathrm{M}_{\mathrm{w}}$ was $2994 \mathrm{~g}$ $\mathrm{mol}^{-1}$ at $250{ }^{\circ} \mathrm{C}$ with a dispersity $(\theta)$ of 5.3 using $\mathrm{MeOH} / \mathrm{H}_{2} \mathrm{O}$. In catalytic SHF using $\mathrm{MeOH} / \mathrm{H}_{2} \mathrm{O}$, extremely low $M_{\mathrm{w}}$ was found $\left(433 \mathrm{mg} \mathrm{g}_{\mathrm{Ls}}{ }^{-1}\right.$ ) with a $\Theta$ of 1.2 combined with $34 \mathrm{mg} \mathrm{g}_{\mathrm{LS}}{ }^{-1}$. The monomer yield was improved to $42 \mathrm{mg} \mathrm{g}_{\mathrm{Ls}}{ }^{-1}$ using dual catalytic beds. These results provide direct evidence that lignin is an unstable polymer at elevated temperatures and could be efficiently deconstructed under hydrothermal conditions with and without a catalyst.
\end{abstract}

Received 13th May 2021,

Accepted 1st September 2021

DOI: $10.1039 / \mathrm{d} 1 \mathrm{gc} 01714 \mathrm{~d}$

rsc.li/greenchem lignin. $^{23-28}$ In 2007, the U.S. Department of Energy (DoE) report posed a milestone for lignin valorization and defined the bio-economy of lignin. ${ }^{29}$ Accordingly, in the report three major valorization scenarios for lignin were defined with respect to their usage in the future: $1^{\text {st }}$ combustion for energy purposes (short term), $2^{\text {nd }}$ application of lignin as a macromolecule (middle term), and $3^{\text {rd }}$ application of lignin as a source of aromatic monomers and oligomers (long term).

Lignin is a complex three-dimensional network of crosslinked phenylpropanoid units connected through different types of ether bonds, i.e., $\beta-\mathrm{O}-4,4-\mathrm{O}-5, \gamma-\mathrm{O}-\alpha$, and carboncarbon bonds, e.g., 5-5 and $\beta-\beta$ linkages, viz. Fig. $1 .^{15,30-34}$ Some of the big challenges in lignin valorization are its heterogeneity, recalcitrance against treatments, and the sensitivity of lignin fragments for follow-up condensation reactions. ${ }^{12,30}$ Currently, four main technologies are used to separate lignin from the other biomass components, i.e., kraft, soda, organosolv and sulfite processes. ${ }^{21,30,35,36}$ These processes rely on lignin separation from the LCB matrix via solubilization by applying harsh conditions with $\mathrm{pH}=1-5$ for sulfite and organosolv or $\mathrm{pH}=11-13$ for soda and kraft, as well as high temperatures $\left(140-220{ }^{\circ} \mathrm{C}\right) .{ }^{21,37}$ The resulting lignin is named technical lignin and is indeed different from the primary plant product. $^{21,37}$ In the DoE Report, the technical lignin is proposed as the most probable future source of lignin since it is abundant and already available from industrial processes, such as the pulping process. ${ }^{29}$ Nowadays, the $1^{\text {st }}$ scenario is still the major application of technical lignin and every year,
Max Planck Institute of Colloids and Interfaces, Colloid Chemistry Department, Am Mühlenberg 1, 14476 Potsdam, Germany. E-mail: majd.al-naji@mpikg.mpg.de $\dagger$ Electronic supplementary information (ESI) available. See DOI: 10.1039/ d1gc01714d 

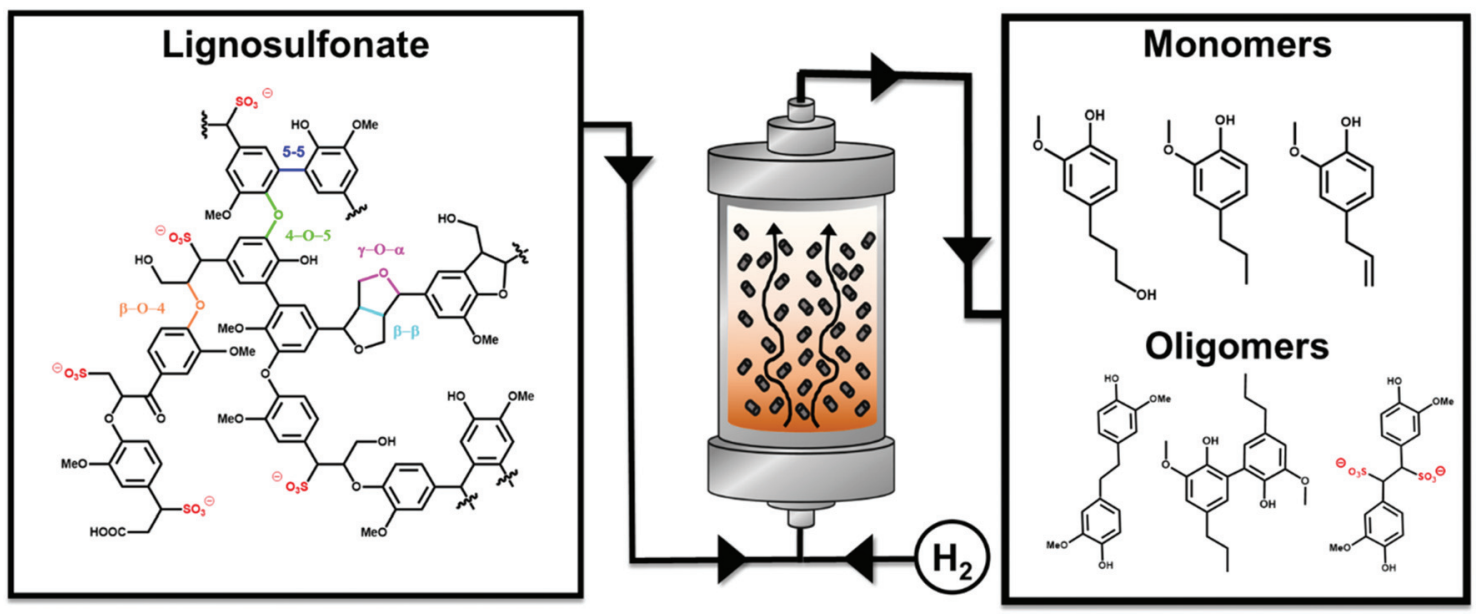

Fig. 1 Route of controlled sodium lignosulfonate (LS) valorization using a continuous flow system.

from the principal $250 \mathrm{Mt}$, about $\sim 70 \mathrm{Mt}$ of technical lignin is separated, of which an estimated $95 \%$ is burned to produce energy. ${ }^{38,39}$ Of that amount, approximately 2 Mt per y are produced only by the sulfite process. ${ }^{21,38}$

In the sulfite pulping, debarked wood chips are treated with sulfite and bisulfite salt solution ( $\mathrm{Na}$ is the major counter-ion to bisulfite) in acidic aqueous media ( $\mathrm{pH} \mathrm{1-5)} \mathrm{at}$ temperatures ranging from 125 to $190{ }^{\circ} \mathrm{C} .{ }^{21,40}$ In this process, the ether bonds in lignin are partially hydrolyzed followed by the sulfitization step (introducing $-\mathrm{SO}_{3}{ }^{-}$functionalities), or oxidative coupling to form parasitic $\mathrm{C}-\mathrm{C}$ bonds. ${ }^{21,29}$ Consequently, the resulting technical lignin is named sodium lignosulfonate (LS). It possesses a wide range of molecular weight $\left(M_{\mathrm{w}}\right)$ from 1000 to $100000 \mathrm{~g} \mathrm{~mol}^{-1}$, the obtained $M_{\mathrm{w}}$ values depend on process severity. ${ }^{21}$ LS contains a large amount of sulfur ( 3 to $8 \mathrm{wt} \%$ ) and a reduced number of $\mathrm{C}-\mathrm{O}$ bonds (Fig. 1) compared to the native lignin in wood. ${ }^{30}$ Uniquely, LS is highly water-soluble due to the presence of $\mathrm{SO}_{3}{ }^{-}$groups. Sulfonate endows LS with surfactant properties and it is used in current materials applications as a macromolecule $\left(2^{\text {nd }}\right.$ scenario), e.g., as superplasticizer in cements and clays ${ }^{41}$ and as dispersing agents for polymeric foams, ${ }^{42,43}$ dyes ${ }^{44}$ and colloidal dispersions. ${ }^{45,46}$ Additionally, LS has been used to create completely new lignin-based materials, e.g., bio-composites for fire-retardant thermal insulators, ${ }^{47,48}$ or S-doped carbonaceous materials for high-performance electrochemical devices such as batteries and supercapacitors. ${ }^{47,49,50}$ All the abovementioned applications have been reported to depend strongly on the molecular weight distribution $\left(M_{\mathrm{w}}\right)$ of the obtained LS. ${ }^{20,48,51}$

As LS has a high phenolic content, it also shows great potential for the production of bio-based aromatics via oxidative or reductive catalytic fractionation (O or RCF) and is considered the $3^{\text {rd }}$ scenario. ${ }^{45,52-56}$ In the last decade, RCF, pioneered by the Sels group, has been reported as one of the methods with the highest potential for lignin valorization towards phenolic single units, mostly starting directly from wood. ${ }^{12,23,28,57-62}$ Based on this process, an approach for the valorisation of lignin toward both phenolic monomers and phenolic oligomers has been proposed to scale up such a process to industry. ${ }^{23,63}$ The simultaneous valorization of monomers and dimers in such an approach has the potential to provide a further step toward the complete usage of lignin in the biorefinery.

Despite the potential of RCF, few studies have been reported using LS solutions. To this end, Shu et al..$^{53}$ reported LS hydrogenolysis using a Pt on a carbon catalyst and $\mathrm{CrCl}_{3}$ homogeneous co-catalyst at $280{ }^{\circ} \mathrm{C}, 3 \mathrm{MPa}$ of $\mathrm{H}_{2}$, in batch systems. Additionally, the effect of a $\mathrm{Ni}$ and Mo bimetallic catalyst on $\mathrm{Al}_{2} \mathrm{O}_{3}$ was studied in ethylene glycol and supercritical ethanol at $310{ }^{\circ} \mathrm{C}$ and 26 bar of $\mathrm{H}_{2}$ in batch systems. $^{64,65}$ This approach led to LS fragmentation mostly towards dimers and oligomers resulting in an optimized $88 \mathrm{wt} \%$ oil yield, while the minor fraction of monomers was only qualitatively studied. ${ }^{64,65}$ All these studies were performed in batch systems, which present disadvantages when compared to continuous flow systems, e.g., complex productcatalyst separation, time and energy-consumption in discontinuous steps and cost efficiency. ${ }^{10,12,59,66,67}$ Horáček et al. ${ }^{52}$ reported only the LS fragmentation in a continuous flow system at a high reaction temperature $\left(320^{\circ} \mathrm{C}\right)$ over a bimetallic $\mathrm{Ni}$ and Mo catalyst supported on $\mathrm{Al}_{2} \mathrm{O}_{3}$. In this study and due to over hydrogenation, guaiacol was found as the major product of LS catalytic fragmentation (yield higher than $1.8 \mathrm{wt} \%)$.

Herein, we investigate the LS depolymerization in a continuous flow system under mild reaction conditions using the water/alcohol solvent system. In addition, the effect of catalystfree solvothermal fragmentation (SF) of LS to low $M_{\mathrm{w}}$ fractions and phenolic monomers was explored. Furthermore, the latter step was coupled to hydrogenolysis/hydrogenation fragmentation (SHF) in a continuous flow system using the water/alcohol solvent and $35 \mathrm{wt} \% \mathrm{Ni}$ supported on NDC as a catalyst. ${ }^{68,69}$ Finally, the advantage of operating the catalytic depolymeriza- 
tion of LS in a continuous flow system is highlighted with respect to the batch system.

\section{Experimental section}

\section{Materials}

All the materials, including sodium lignosulfonate (LS), were utilized as received without further purification. The complete list of chemicals used, suppliers, and purities can be found in section $\mathrm{S} 1$ of the ESI. $\dagger$

\section{Catalyst synthesis and characterization}

A pelletized catalyst of $35 \mathrm{wt} \% \mathrm{Ni}$ deposited on nitrogendoped carbon (35Ni/NDC) has been synthesized and characterized following the "kitchen lab" approach, as previously reported by our group, $c f$. sections $\mathrm{S} 2$ and S3 in the ESI. $\dagger^{68}$ The catalyst was characterized via combustion elemental analysis (EA), inductively coupled plasma (ICP) optical emission spectroscopy elemental analysis, N2 physisorption, powder X-ray diffraction (XRD), thermogravimetric analysis (TGA), high-resolution scanning transmission electron microscopy (HR-STEM), and energy-dispersive X-ray spectrometry (EDS) and CO-chemisorption. All procedures of catalyst characterization are described in detail in section S3 in the ESI. $\dagger$

\section{Continuous flow setup}

Liquid-phase LS depolymerization using water/alcohol solvent mixtures was conducted in a continuous flow fixed bed reactor, similar to our previously described system (Fig. S2 in the ESI $\dagger)^{68-70}$

This system consists of: (A) an HPLC pump equipped with a pressure sensor (Knauer Azura P 4.1S Series), (B) a mass-flow controller to supply a specific $\mathrm{H}_{2}$ flow (Model SLA58050 from Brooks), (C) a T-piece for the gas-liquid mixer (Swagelok SS-400-30) to mix the supplied $\mathrm{H}_{2}$ with the reaction solution before reaching the pre-heating unit and the catalyst bed, (D) a two-side open heating unit equipped with a heat controller (Model \# 4848 from Parr Instrument Company), and (E) a sampling unit equipped with proportional relief valves also used as a pressure regulator (Swagelok SS-RL4M8F8-EP), $c f$. Fig. S2 in the ESI. $\dagger$ To ensure efficient heating, a cylindrical aluminium adapter with three boreholes was matched inside the heating unit. One bore is used for the preheating unit for the reactant before it comes in contact with the catalyst, another hole for the thermocouple (Model \# A472E5 Parr Instrument Company) and the third one for the tubular reactor (Fig. S3 in the ESI $\dagger$ ). The reactions were performed in a stainless steel tubular reactor (inner diameter $=21 \mathrm{~mm}$, outer diameter $=25 \mathrm{~mm}$, length $=280 \mathrm{~mm}$ ), viz. Fig. S4 in the ESI. $\dagger$ Finally, an experiment using two consecutive fixed bed reactors filled with $10 \mathrm{~g}$ each of $35 \mathrm{Ni} / \mathrm{NDC}$ was conducted. To perform these experiments two fixed bed reactors (D1-D2) were coupled in a setup similar to the one described above (Fig. S5 in the ESI†).

\section{Catalytic experiments}

Prior to each experiment, the LS solution $\left(c_{\mathrm{LS}}=1.0 \mathrm{wt} \%\right.$ or $2.5 \mathrm{wt} \%$ ) was filtered through filter paper (Whatman ${ }^{\mathrm{TM}}$ grade $40,8 \mu \mathrm{m})$ to remove any solid residues that could cause clogging of the continuous flow system. In a typical experiment, the solution of LS was fed by the HPLC pump at $1.0 \mathrm{~cm}^{3}$ $\min ^{-1}$, then mixed with $\mathrm{H}_{2}\left(20 \mathrm{~cm}^{3} \min ^{-1}\right)$ and passed through the preheating unit and the tubular reactor. The temperature and pressure were kept constant $\left(25{ }^{\circ} \mathrm{C}\right.$ and atmospheric pressure) for 30 minutes at this steady state. Afterwards, the system was pressurized to 7.0 MPa to ensure the presence of the water/alcohol solvent system in the liquid state. Later, the system was heated to the desired reaction temperature $\left(150{ }^{\circ} \mathrm{C}, 200{ }^{\circ} \mathrm{C}\right.$ and $\left.250{ }^{\circ} \mathrm{C}\right)$. In each catalytic experiment, $10 \mathrm{~g}$ of catalyst mass was used. Samples $\left(30 \mathrm{~cm}^{3}\right)$ were collected once the steady-state was reached (ca. $60 \mathrm{~min}$ ). For the time on stream (TOS) experiment, samples were collected after $1 \mathrm{~h}, 3 \mathrm{~h}, 6 \mathrm{~h}$, and $9 \mathrm{~h}$ of TOS. In the case of the two coupled reactors, a second, similarly filled reactor was mounted after the first reactor, and the same conditions were used as in the single reactor experiments. Samples were collected once both systems reached the steady-state (ca. $120 \mathrm{~min}$ ).

The collected samples were injected into a size exclusion chromatography (SEC) system without further processing, while the product analysis procedure was established to separate the residual LS from the reaction mixture, and therefore analyze the separated mixtures by GC-MS, GC-FID, 2D HSQC NMR, FTIR, elemental analysis and EDS. The established product analysis procedure is described in detail in the ESI in section S5. $\dagger$

The batch experiment was conducted in a stainless steel autoclave equipped with PTFE liners and a magnetic stirrer from Berghof (Model: BR-100). The catalytic experiments were performed at $250{ }^{\circ} \mathrm{C}$ using $30 \mathrm{~cm}^{3}$ of LS solution in a $\mathrm{MeOH} /$ $\mathrm{H}_{2} \mathrm{O}$ solvent mixture $\left(c_{\mathrm{LS}}=2.5 \mathrm{wt} \%\right)$ with $1.0 \mathrm{~g}$ of $35 \mathrm{Ni} / \mathrm{NDC}$ and 7.0 $\mathrm{MPa}$ of external $\mathrm{H}_{2}$ pressure for 1 and $3 \mathrm{~h}$. Prior to heating to $250{ }^{\circ} \mathrm{C}$, air was purged out using $1.0 \mathrm{MPa}$ of $\mathrm{N}_{2}$ three times. The analysis of the reaction products followed the same protocol that was established for the continuous flow experiments.

\section{Results and discussion}

\section{Composition analysis of sodium lignosulfonate}

Initially, the chemical composition of the utilized commercially available sodium lignosulfonate (LS) was investigated via elemental analysis, (Table 1). The LS was found to contain $7.0 \mathrm{wt} \%$ of sulfur (Table 1). This S content is comparable to the reported industrial sulfite process by Borregaard. ${ }^{21,43}$ This indicates a high sulfonation degree and consequentially a high content of counter ions. In this context, Na was found to be the major sulfonate counter ion with $10 \mathrm{wt} \%$, combined with the presence of $\mathrm{Ca}$ and $\mathrm{Mg}$ traces (Table 1). The presence of these $\mathrm{Ca}$ and $\mathrm{Mg}$ ions points to the usage of mixed sulfite salts 
Table 1 Chemical composition, and textural and size properties of LS

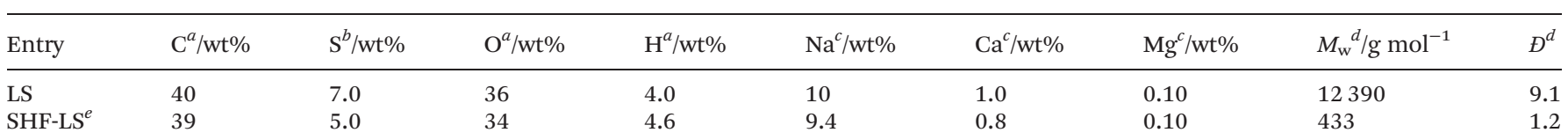

${ }^{a}$ Measured via EA analysis. ${ }^{b}$ Measured by EDS. ${ }^{c}$ Measured via ICP-OES. ${ }^{d}$ Calculated by SEC. ${ }^{e}$ Referred to the SHF-MeOH/H $\mathrm{O}$ experiment.

containing $\mathrm{Na}, \mathrm{Ca}$ and $\mathrm{Mg}$ in the industrial isolation process. $^{21}$ Moreover, TGA analysis for LS showed a relatively high residual mass at $700{ }^{\circ} \mathrm{C}$ of $56 \mathrm{wt} \%$, confirming the high sulfonation degree, $c f$. Fig. S7 in the ESI. $\dagger$ Finally, the moisture content was found to be $4.5 \mathrm{wt} \%$, as determined by TGA analysis (see Table 1 and Fig. S7 in the ESI $\dagger$ ).

The SEC analysis of an aqueous LS solution (1 wt\%) showed a weight average molecular weight $\left(M_{\mathrm{w}}\right)$ of $12390 \mathrm{~g} \mathrm{~mol}^{-1}$ with a dispersity $(D)$ of 9.1, viz. Fig. S8 in the ESI. $\dagger$ This high $D$ value indicates that LS presents a polydisperse distribution of the molecular weight. The 2D HSQC NMR spectra of the LS showed the absence of syringyl units (S), and only guaiacyl units $(\mathrm{G})$ have been found in the typical aromatic region $\left(\delta_{\mathrm{C}} / \delta_{\mathrm{H}}\right.$ 100-150/6.2-7.5), viz. Fig. S9 in the ESI. $\uparrow^{71,72}$ This indicates that the utilized LS in this work has been produced from softwood, in which the S/G molar ratio is zero. Generally, lignin rich in $G$ units is favorable for certain applications such as additives for polymers and resins. This is due to the reactive ortho-position of the phenolic rings, which promotes radicalinitiated crosslinking. ${ }^{73}$ 2D HSQC NMR of LS showed the presence of sulfo-groups in the $\alpha$ position $\left(\alpha-\mathrm{S}_{\alpha, \beta, \gamma}\right)$ at $\delta_{\mathrm{C}} / \delta_{\mathrm{H}}$ of 66-68/4.5-4.7, 79-82/4.7-5.1 and 60-62/3.9-4.0, respectively. These are typical for LS, viz. Fig. S9 in the ESI. $\uparrow^{71,72}$ Moreover as expected, FTIR analysis showed the typical $\mathrm{O}-\mathrm{H}$ stretching bond at around $3400 \mathrm{~cm}^{-1}$, the asymmetric and symmetric $\mathrm{O}=\mathrm{S}=\mathrm{O}$ stretching at $1150-1200 \mathrm{~cm}^{-1}$ and $1036 \mathrm{~cm}^{-1}$ and the typical signals of the aromatic ring vibration at around $1400 \mathrm{~cm}^{-1}$ respectively, viz. Fig. S10 and Table S1 in the ESI. $\dagger^{74}$

\section{Solvothermal fragmentation (SF) of sodium lignosulfonate}

The usage of short chain bio-derivable alcohol such as ethanol $(\mathrm{EtOH})$ and methanol $(\mathrm{MeOH})$, as well as their mixture with water, has been reported as efficient solvent mixtures for both lignin extraction and fractionation. ${ }^{57,75-78}$ Due to the low solubility of LS in organic solvents, an aqueous solvent mixture, i.e., $\mathrm{MeOH} / \mathrm{H}_{2} \mathrm{O}$ and EtOH$/ \mathrm{H}_{2} \mathrm{O}$, is necessary. ${ }^{39}$ Therefore, the efficiency of water/alcohol mixtures $\left(\mathrm{MeOH} / \mathrm{H}_{2} \mathrm{O}\right.$ and EtOH/ $\mathrm{H}_{2} \mathrm{O}$ with $1: 1$ weight ratio) and of pure $\mathrm{H}_{2} \mathrm{O}$ as a solvent was studied for the catalyst-free solvothermal fragmentation (SF) of LS.

The solvothermal fragmentation reactions (SF) were performed at $150{ }^{\circ} \mathrm{C}, 200{ }^{\circ} \mathrm{C}$, and $250{ }^{\circ} \mathrm{C}$ in the absence of the catalyst. In all cases, i.e., using $\mathrm{MeOH} / \mathrm{H}_{2} \mathrm{O}$ and $\mathrm{EtOH} / \mathrm{H}_{2} \mathrm{O}$ mixtures and $\mathrm{H}_{2} \mathrm{O}$ as the solvent, the SEC elugrams exhibited the successive disappearance of the peak at low retention times (<10 min), corresponding to the high molecular weight fraction, $c f$. Fig. 2 and Fig. S11 in the ESI. $\dagger$ For the $\mathrm{MeOH} / \mathrm{H}_{2} \mathrm{O}$ solvent mixture, the derived mass average molecular weight

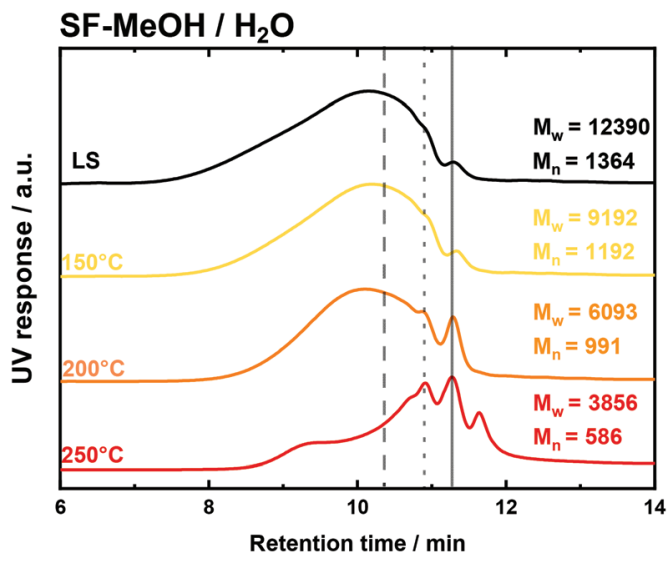

Fig. 2 SEC chromatograms of the solvothermal fragmentation (SF) of $\mathrm{LS}$ in $\mathrm{MeOH} / \mathrm{H}_{2} \mathrm{O}$. Reaction conditions: $C_{\mathrm{LS}}=1.0 \mathrm{wt} \%, T=150^{\circ} \mathrm{C}, 200^{\circ} \mathrm{C}$ and $250^{\circ} \mathrm{C}, p=7.0 \mathrm{MPa}, Q_{\text {educt }}=1.0 \mathrm{~cm}^{3} \mathrm{~min}^{-1}, Q_{\mathrm{H}_{2}}=20 \mathrm{~cm}^{3}$ $\mathrm{min}^{-1}$ and $t_{\text {residence }}=50 \mathrm{~min}$. The straight line indicates the eluent buffer reference peak $\left(\mathrm{NaHPO}_{3}\right)$, dotted and dashed lines show the analytical standard peaks, i.e., sodium poly-(styrene sulfonate), with a $M_{\mathrm{w}}$ of $246 \mathrm{~g}$ $\mathrm{mol}^{-1}(\mathrm{RT}=10.9 \mathrm{~min})$ and $M_{\mathrm{w}}$ of $891 \mathrm{~g} \mathrm{~mol}^{-1}(\mathrm{RT}=10.4 \mathrm{~min})$, respectively.

$\left(M_{\mathrm{w}}\right)$ was decreased from $12390 \mathrm{~g} \mathrm{~mol}^{-1}$ for untreated LS to $9132 \mathrm{~g} \mathrm{~mol}^{-1}, 6093 \mathrm{~g} \mathrm{~mol}^{-1}$ and $3856 \mathrm{~g} \mathrm{~mol}^{-1}$ following the increase of reaction temperature to $150{ }^{\circ} \mathrm{C}, 200^{\circ} \mathrm{C}$ and $250{ }^{\circ} \mathrm{C}$, respectively (Fig. 2, Table S2 - entries 2 to 4 and Fig. S12 in the ESI $\dagger$ ). Similarly, the EtOH/ $\mathrm{H}_{2} \mathrm{O}$ solvent mixture showed a decrease of $M_{\mathrm{w}}$ with the increase of reaction temperatures, i.e., from $150{ }^{\circ} \mathrm{C}$ to $200{ }^{\circ} \mathrm{C}$ and to $250{ }^{\circ} \mathrm{C}$, giving the lowest $M_{\mathrm{w}}$ value of $3000 \mathrm{~g} \mathrm{~mol}^{-1}$ at $250{ }^{\circ} \mathrm{C}$, viz. Fig. 3, Table S2 - entries 5 to 7 and Fig. S12 in the ESI. $\dagger$ Also using pure $\mathrm{H}_{2} \mathrm{O}$ as a solvent, the $M_{\mathrm{w}}$ was found to be following the same behaviour, i.e. decreasing with the temperature increase, with the lowest $M_{\mathrm{w}}$ of $5578 \mathrm{~g} \mathrm{~mol}^{-1}$ at $250{ }^{\circ} \mathrm{C}$ (Fig. 3, Table S2 - entries 8 to 10 and Fig. S12 in the ESI $\dagger$ ). Analogously to $M_{\mathrm{w}}$, the number averaged molecular weight distribution $\left(M_{\mathrm{n}}\right)$ decreased with the increase of the reaction temperatures, giving the minimum at $250{ }^{\circ} \mathrm{C}$, i.e., $M_{\mathrm{n}}=586 \mathrm{~g} \mathrm{~mol}^{-1}, 556 \mathrm{~g} \mathrm{~mol}^{-1}$ and $957 \mathrm{~g} \mathrm{~mol}^{-1}$ for MeOH/ $\mathrm{H}_{2} \mathrm{O}, \mathrm{EtOH} / \mathrm{H}_{2} \mathrm{O}$ and $\mathrm{H}_{2} \mathrm{O}$ respectively, $c f$. Fig. S12 and Table S2 - entries 4, 7, and 10 in the ESI. $\dagger$

The significant decrease in the molecular weight in all cases indicates that the cleavage of the weaker linkages of LS (mostly phenyl ether bonds) has already occurred at the lower reaction temperatures, i.e., $150{ }^{\circ} \mathrm{C}$ and $200{ }^{\circ} \mathrm{C}$. Rather expectedly, this fragmentation is becoming most effective at the highest applied temperature, i.e., $250{ }^{\circ} \mathrm{C}$. However, the molecular weight dispersity $(D)$ was found to be higher than 5.0 at 


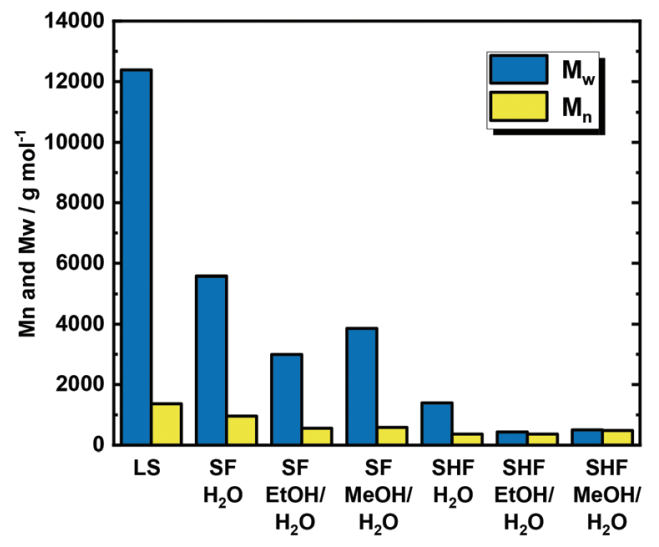

Fig. 3 Mass average molecular weight $\left(M_{w}\right)$ and number average molecular weight $\left(M_{n}\right)$ calculated from SEC curves for the solvothermal fragmentation (SF) of LS and solvothermal combined with catalytic hydrogenolysis/hydrogenation (SHF) using $\mathrm{MeOH} / \mathrm{H}_{2} \mathrm{O}, \mathrm{EtOH} / \mathrm{H}_{2} \mathrm{O}$, and $\mathrm{H}_{2} \mathrm{O}$ solvent systems. Reaction conditions of $\mathrm{SF}: C_{\mathrm{LS}}=1.0 \mathrm{wt} \%, T=250^{\circ} \mathrm{C}, p$ $=7.0 \mathrm{MPa}, Q_{\text {educt }}=1.0 \mathrm{~cm}^{3} \mathrm{~min}^{-1}, Q_{\mathrm{H}_{2}}=20 \mathrm{~cm}^{3} \mathrm{~min}^{-1}$ and $t_{\text {residence }}=$ $50 \mathrm{~min}$. Reaction conditions of SHF: $c_{\mathrm{LS}}=1.0 \mathrm{wt} \%, T=250^{\circ} \mathrm{C}, p=7.0$ $\mathrm{MPa}, Q_{\text {educt }}=1.0 \mathrm{~cm}^{3} \mathrm{~min}^{-1}, Q_{\mathrm{H}_{2}}=20 \mathrm{~cm}^{3} \mathrm{~min}^{-1}, m_{35 \mathrm{Ni} / \mathrm{NDC}}=10 \mathrm{~g}, t_{\text {resi- }}$ dence $=50 \mathrm{~min}$, and weight hour space velocity (WHSV) $=0.17 \mathrm{gLs} \mathrm{h}^{-1}$ $\mathrm{gNi}^{-1}$.

all of the investigated temperatures using all solvent systems (Table S2 - entries 2 to 10 - in the ESI†). This indicates that fragmentation occurred only partially, resulting in a heterogeneous mixture with different sizes of oligomers, mostly tri-, tetra- and pentamers. An additional explanation for such a heterogeneous molar mass distribution could be attributed to in situ re-polymerization (side reactions) of the cleaved intermediates or the occurrence of radical polymerization. ${ }^{79}$ Nonetheless, the water/alcohol mixtures exhibited lower molar mass distributions over all the investigated temperatures. This result is attributed to the better stabilization of the intermediates against re-condensation by water/alcohols mixtures. Based on this, $\mathrm{MeOH} / \mathrm{H}_{2} \mathrm{O}$ and $\mathrm{EtOH} / \mathrm{H}_{2} \mathrm{O}$ samples were selected to qualitatively analyse the monomers using GC-MS, viz. Fig. S13 in the ESI. $\uparrow$ From this chromatogram, a wide range of monomers (16 compounds) has been identified and reported in Table S3 in the ESI. $\dagger$ Moreover, the GC-MS chromatogram exhibited peaks in the high retention time region $(>20 \mathrm{~min})$, which can be attributed to dimers. However, these dimers were not identified and recognized by the compound database of the GC device. Among the identified compounds, 4-propyl guaiacol (G1), 4-ethyl guaiacol (G2), homovanillyl alcohol (G3), dihydroconyferyl alcohol (G4), guaiacol (G5) creosol (G6), eugenol (G7) and isoeugenol (G8) were quantified using GC-FID, and cumulative monomer yields of $8.7 \mathrm{mg} \mathrm{g}_{\mathrm{LS}}{ }^{-1}$ and $2.9 \mathrm{mg} \mathrm{g} \mathrm{LS}^{-1}$ were calculated for $\mathrm{MeOH} / \mathrm{H}_{2} \mathrm{O}$ and $\mathrm{EtOH} / \mathrm{H}_{2} \mathrm{O}$, respectively (Table 2 and Fig. S14 in the ESI $\dagger$ ). These higher cumulative monomer yields are attributed to better monomer stabilization by the $\mathrm{MeOH} / \mathrm{H}_{2} \mathrm{O}$ solvent mixtures. It is noteworthy to be mentioned here that SF in continuous flow systems produced partially depolymerized LS. In this simple approach, the molecular weight distribution has been found to depend directly on the reaction temperature. This finding can be attributed to the thermal elimination of single phenol units from LS. This is a typical behaviour of a thermodynamically unstable polymer that undergoes reversible addition-fragmentation reactions. Moreover, the derived dispersity $\left(D=6.5\right.$ at $250{ }^{\circ} \mathrm{C}$ using $\left.\mathrm{MeOH} / \mathrm{H}_{2} \mathrm{O}\right)$ indicates that this equilibrium is perturbed by side reactions such as condensation of the cleaved fragments. This phenomenon provides clear evidence of the presence of a ceiling temperature, above which the polymer is spontaneously depolymerized into smaller units. Interestingly, the presence of a ceiling temperature is a general phenomenon in polymer science but was mostly not reported in the community of lignin biorefinery. ${ }^{80}$

\section{Solvothermally assisted catalytic hydrogenolysis/hydrogenation fragmentation (SHF) of sodium lignosulfonate}

Primarily, the utilized $35 \mathrm{Ni} / \mathrm{NDC}$ in pellet form was synthesized using our "kitchen lab" approach that was previously

Table 2 Yield of the quantified monomers in the SF and SHF experiments. Monomers: 4-propyl guaiacol (G1), 4-ethyl guaiacol (G2), homovanillyl alcohol (G3), dihydroconyferyl alcohol (G4), guaiacol (G5), creosol (G6), eugenol (G7), isoeugenol (G8), and 4-propyl phenol (H1). The compound structure and the reaction conditions are reported in the main body of the manuscript

\begin{tabular}{|c|c|c|c|c|c|c|c|c|c|c|c|c|c|}
\hline Sample & $\begin{array}{l}c_{\mathrm{LS}} / \\
\mathrm{wt} \%\end{array}$ & $\begin{array}{l}T / \\
{ }^{\circ} \mathrm{C}\end{array}$ & $\begin{array}{l}\mathrm{G} 1 / \mathrm{mg} \\
\mathrm{g}_{\mathrm{LS}}{ }^{-1}\end{array}$ & $\begin{array}{l}\mathrm{G} 2 / \mathrm{mg}^{-1} \\
\mathrm{~g}_{\mathrm{LS}}{ }^{-1}\end{array}$ & $\begin{array}{l}\mathrm{G} 3 / \mathrm{mg} \\
\mathrm{g}_{\mathrm{LS}}{ }^{-1}\end{array}$ & $\begin{array}{l}\mathrm{G} 4 / \mathrm{mg} \\
\mathrm{g}_{\mathrm{LS}}{ }^{-1}\end{array}$ & $\begin{array}{l}\mathrm{G} 5 / \mathrm{mg} \\
\mathrm{g}_{\mathrm{LS}}{ }^{-1}\end{array}$ & $\begin{array}{l}\mathrm{G} 6 / \mathrm{mg} \\
\mathrm{g}_{\mathrm{LS}}{ }^{-1}\end{array}$ & $\begin{array}{l}\mathrm{G} 7 / \mathrm{mg}^{-1} \\
\mathrm{~g}_{\mathrm{LS}}{ }^{-1}\end{array}$ & $\begin{array}{l}\mathrm{G} 8 / \mathrm{mg}^{-1} \\
\mathrm{~g}_{\mathrm{LS}}{ }^{-1}\end{array}$ & $\begin{array}{l}\mathrm{H} 1 / \mathrm{mg} \\
\mathrm{g}_{\mathrm{LS}}{ }^{-1}\end{array}$ & $\begin{array}{l}Y_{\mathrm{CM}^{-1}} / \mathrm{mg} \\
\mathrm{g}_{\mathrm{LS}}\end{array}$ & $\begin{array}{l}\mathrm{STY}_{\mathrm{CM}} / \mathrm{mg} \\
\mathrm{h}^{-1} \mathrm{~g}_{\mathrm{Ni}}{ }^{-1}\end{array}$ \\
\hline $\begin{array}{l}\text { SF-MeOH/ } \\
\mathrm{H}_{2} \mathrm{O}\end{array}$ & 1 & 250 & 1.2 & 0.48 & 1.5 & 0.94 & 0.80 & 0.04 & 3.4 & 0.35 & n.a. & 8.7 & n.a. \\
\hline SF-EtOH $/ \mathrm{H}_{2} \mathrm{O}$ & 1 & 250 & 0.89 & 0.01 & n.a. & 0.94 & 0.93 & 0.05 & n.a. & 0.10 & n.a. & 2.9 & n.a. \\
\hline SHF-MeOH/ & 1 & 150 & 6.7 & 0.22 & n.a. & 0.72 & 0.80 & 0.46 & n.a. & n.a. & 0.19 & 9.1 & 1.6 \\
\hline \multirow[t]{2}{*}{$\mathrm{H}_{2} \mathrm{O}$} & 1 & 200 & 6.6 & 0.35 & 2.9 & 5.1 & 0.89 & 0.04 & n.a. & n.a. & 0.37 & 16 & 2.7 \\
\hline & 1 & 250 & 16 & 2.7 & 3.1 & 8.2 & 2.2 & 0.22 & n.a. & n.a. & 0.83 & 34 & 5.8 \\
\hline & 1 & 250 & 17 & 0.72 & 2.4 & 9.7 & 0.78 & 0.10 & n.a. & n.a. & 0.53 & 31 & 5.3 \\
\hline Flow 2.5 wt\% & 2.5 & 250 & 16 & 4.9 & 0.71 & 5.6 & 3.7 & 1.6 & n.a. & n.a. & 0.1 & 33 & 14 \\
\hline Dual column & 2.5 & 250 & 20 & 5.7 & 0.94 & 9.6 & 3.4 & 1.6 & n.a. & n.a. & 0.2 & 42 & 9.0 \\
\hline Batch $1 \mathrm{~h}$ & 2.5 & 250 & 12 & 0.70 & 2.0 & 1.9 & 1.3 & 0.17 & 0.53 & 0.48 & n.a. & 19 & n.a. \\
\hline
\end{tabular}

n.a. = not applicable. Note: The reaction conditions of these experiments can be found in the captions of Fig. 2, 3, 4, 5, 6 and S11 at ESI. $\dagger$ 
reported. ${ }^{64-66}$ The $\mathrm{N}_{2}$ sorption isotherms of the parent carbonized NDC and 35Ni/NDC represent type IV isotherms (Fig. S15 in the ESI $\dagger$ ), which is characteristic of mesoporous materials. NDC and 35Ni/NDC exhibited high specific surface areas of $755 \mathrm{~m}^{2} \mathrm{~g}^{-1}$ and $578 \mathrm{~m}^{2} \mathrm{~g}^{-1}$ (Table $\mathrm{S} 4$ in the ESI $\dagger$ ), respectively. This combined with a $\mathrm{C} / \mathrm{N}$ ratio of 22 indicates relatively high $\mathrm{N}$ doping (Table $\mathrm{S} 4$ in the ESI $\dagger$ ). XRD of the $35 \mathrm{Ni} / \mathrm{NDC}$ catalyst showed the typical reflection of $\mathrm{Ni}^{0}$ at $44^{\circ}$ and $51^{\circ}$, indicating the complete reduction of $\mathrm{NiO}$ formed in the calcination step, viz. Fig. S16 in the ESI. $\uparrow$ The HR-TEM images also showed Ni nanoparticles of the expected size, i.e. 20-40 nm, viz. Fig. S17 in the ESI. $\dagger$ These findings are in agreement with the crystalline size from CO-TPD of $21 \mathrm{~nm}$, which is correlated to the Ni surface area of $21 \mathrm{~m}^{2} \mathrm{~g}^{-1}, c f$. Table S4 in the ESI. $\dagger$

In this part, the influence of coupling a catalytic hydrogenolysis/hydrogenation step with the abovementioned solvothermal treatment on LS depolymerization was investigated. Herein, the presence of a redox catalyst (35Ni/NDC) facilitates LS depolymerization through hydrogenolysis of ether bonds of LS fragments, mostly $\beta-\mathrm{O}-4$, and $4-\mathrm{O}-5$ (viz. Fig. S18 in the ESI $\dagger$ ). Simultaneously, the unsaturated and unstable fragments formed solvothermally are catalytically hydrogenated, preventing their recondensation (viz. Fig. S18 in the ESI $\dagger$ ). ${ }^{59,81}$ For this purpose, a set of experiments was performed at three different reaction temperatures, i.e., $150{ }^{\circ} \mathrm{C}, 200{ }^{\circ} \mathrm{C}$ and $250{ }^{\circ} \mathrm{C}$, using water/alcohol with a weight ratio of $1: 1$, i.e., $\mathrm{EtOH} / \mathrm{H}_{2} \mathrm{O}$ and $\mathrm{MeOH} / \mathrm{H}_{2} \mathrm{O}$, as well as using only $\mathrm{H}_{2} \mathrm{O}$ as a solvent. These experiments are noted as follows: SHF-MeOH/ $\mathrm{H}_{2} \mathrm{O}$, SHF-EtOH/ $\mathrm{H}_{2} \mathrm{O}$, and SHF- $\mathrm{H}_{2} \mathrm{O}$.

The dependence of the molecular weight (from SEC) on the reaction temperature in these experiments is shown in Fig. 4 and Fig. S19. $\dagger$ By increasing the reaction temperature from $150{ }^{\circ} \mathrm{C}$ to $200{ }^{\circ} \mathrm{C}$ and to $250{ }^{\circ} \mathrm{C}$, the SEC elugrams showed a disappearance of the peak at low retention time ( $\mathrm{RT}<9 \mathrm{~min}$ ), which corresponds to the high molecular weight fraction, in all solvent systems. Similarly, $M_{\mathrm{w}}$ and $M_{\mathrm{n}}$ exhibited significant decay when the temperature was increased from $150{ }^{\circ} \mathrm{C}$ to $200{ }^{\circ} \mathrm{C}$ and to $250{ }^{\circ} \mathrm{C}$ for SHF-MeOH$/ \mathrm{H}_{2} \mathrm{O}, \mathrm{SHF}-\mathrm{MeOH} / \mathrm{H}_{2} \mathrm{O}$ and SHF- $\mathrm{H}_{2} \mathrm{O}$, viz. Fig. 3, Fig. S19, and S20 in the ESI. $\uparrow$ The $M_{\mathrm{w}}$ was found to have decreased from $12390 \mathrm{~g} \mathrm{~mol}^{-1}$ (before reaction) to $433 \mathrm{~g} \mathrm{~mol}^{-1}, 502 \mathrm{~g} \mathrm{~mol}^{-1}$ and $1393 \mathrm{~g} \mathrm{~mol}^{-1}$ at $250{ }^{\circ} \mathrm{C}$ for SHF-MeOH/ $\mathrm{H}_{2} \mathrm{O}$, SHF-EtOH/ $\mathrm{H}_{2} \mathrm{O}$, and SHF- $\mathrm{H}_{2} \mathrm{O}$, respectively (Fig. 4 and Table S2 - entries 13 and 16 in the ESI $\dagger$ ). All these values are smaller than those for SF (Table S2 - entries 4, 7 and 10 - in the ESI $\dagger$ ).

Nevertheless, using pure $\mathrm{H}_{2} \mathrm{O}$ as a solvent resulted in a higher molecular weight at all investigated temperatures compared to its water/alcohol counterparts. This observation is in agreement with the SF experiments, wherein using pure water as a solvent lead to the formation of oligomers and dimers. ${ }^{77,82}$ Moreover, $Ð$ has substantially decreased from 6.5 to 1.2 for SHF-MEOH/ $\mathrm{H}_{2} \mathrm{O}$ and SHF-EtOH/ $\mathrm{H}_{2} \mathrm{O}$, and to 3.8 for $\mathrm{SHF}-\mathrm{H}_{2} \mathrm{O}$ i.e., from highly dispersed to relatively monodisperse (Table S2 - entries 4 and 13 in the ESI†). This decrease of both $Ð$ and $M_{\mathrm{W}}$ in SHF clearly indicates a controlled and efficient LS

\section{SHF-MeOH / $\mathrm{H}_{2} \mathrm{O}$}

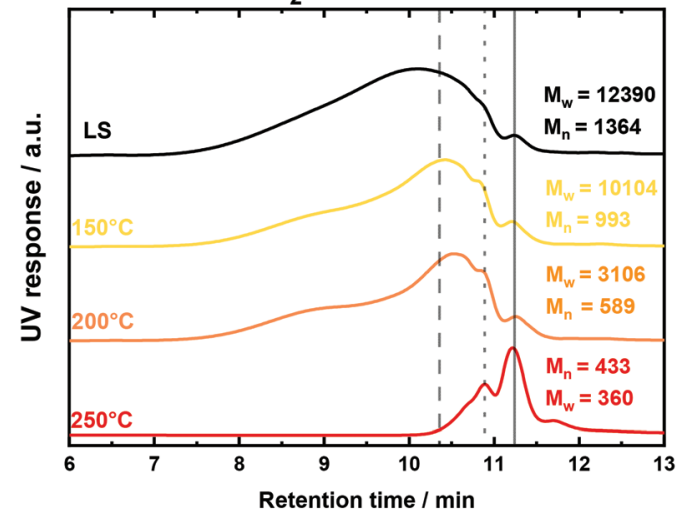

SHF-EtOH $/ \mathrm{H}_{2} \mathrm{O}$

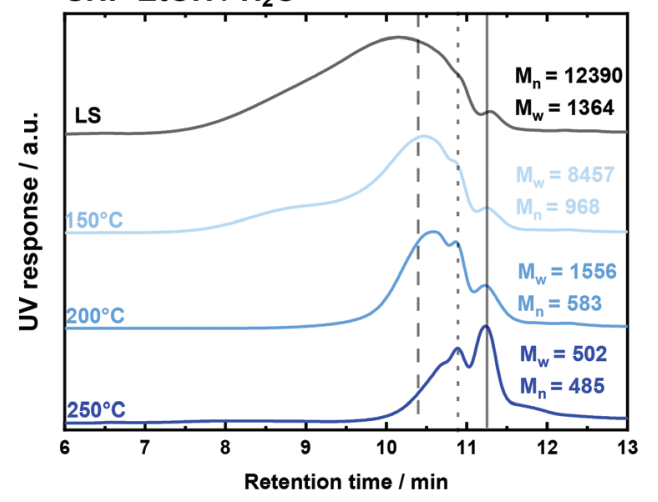

Fig. 4 SEC elugrams for SHF of LS using $\mathrm{MeOH} / \mathrm{H}_{2} \mathrm{O}$ (top) and EtOH/ $\mathrm{H}_{2} \mathrm{O}$ (bottom). Reaction conditions: $c_{\mathrm{LS}}=1.0 \mathrm{wt} \%, \mathrm{~T}=150{ }^{\circ} \mathrm{C}, 200{ }^{\circ} \mathrm{C}$ and $250^{\circ} \mathrm{C}, p=7.0 \mathrm{MPa}, Q_{\text {educt }}=1.0 \mathrm{~cm}^{3} \mathrm{~min}^{-1}, Q_{\mathrm{H}_{2}}=20 \mathrm{~cm}^{3} \mathrm{~min}^{-1}$, $m_{35 \mathrm{Ni} / \mathrm{NDC}}=10.0 \mathrm{~g}, t_{\text {residence }}=50 \mathrm{~min}$, and weight hour space velocity $($ WHSV $)=0.17 \mathrm{~g}_{\mathrm{LS}} \mathrm{h}^{-1} \mathrm{gNi}^{-1}$. The straight line indicates the eluents buffer reference peak $\left(\mathrm{NaHPO}_{3}\right)$, dotted and dashed lines show the analytical standard peaks, i.e., sodium polystyrene sulfonate, with $M_{\mathrm{w}}$ of $246 \mathrm{~g}$ $\mathrm{mol}^{-1}$ (RT = $10.9 \mathrm{~min}$ ) and $M_{\mathrm{w}}$ of $891 \mathrm{~g} \mathrm{~mol}^{-1}(\mathrm{RT}=10.4 \mathrm{~min}$ ), respectively.

depolymerization in the presence of the catalyst with respect to SF. These observations are in good agreement with the proposed stabilization of the formed monomers via hydrogenolysis/hydrogenation due to the presence of both $\mathrm{H}_{2}$ and the redox catalyst. Thus, this step is required to prevent recondensation of the fragmented fraction. ${ }^{59,81}$

For detailed insights into the structure of the sample taken from SHF-MeOH/ $\mathrm{H}_{2} \mathrm{O}$ at $250{ }^{\circ} \mathrm{C}$, characterization of the freeze dried solid residue (denoted as SHF-LS) was performed via elemental analysis (EA) including analysis of $\mathrm{Na}, \mathrm{Ca}$, and $\mathrm{Mg}$ via ICP-OES, FTIR and 2D HSQC NMR. The EA showed a decrease of the $\mathrm{S}$ content from $7.0 \mathrm{wt} \%$ to $5.0 \mathrm{wt} \%$, while the O content decreased slightly from $36 \mathrm{wt} \%$ to $34 \mathrm{wt} \%, c f$. Table 1. Differently, the $\mathrm{Na}, \mathrm{Ca}$ and $\mathrm{Mg}$ amounts in the freezedried solid residue remained constant before and after the experiment. The difference in the S content is attributed to the elimination of sodium sulfate and sodium sulfide as a result of sulfonate hydrolysis and reduction. We also find a slightly higher acidity of the product solution $(\mathrm{pH}=5.5)$ when com- 
pared to the reactant solution $(\mathrm{pH}=6.3)$. It is important to note that at this $\mathrm{pH}$, the water soluble phenolates are not formed without subsequent loss of aromatics in the water phase. The 2D HSQC NMR spectra for SHF-LS showed the disappearance of the sulfo-group signals $\left(\alpha-\mathrm{S}_{\alpha, \beta, \gamma}\right.$ at $\delta_{\mathrm{C}} / \delta_{\mathrm{H}} 66-68 /$ 4.5-4.7, 79-82/4.7-5.1 and 60-62/3.9-4.0), which is an indication of the sulfonate group removal from LS (Fig. S21 in the ESI $\dagger$ ). In addition, low intensity of $\mathrm{Ni}_{2} \mathrm{~S}_{3}$ with respect to $\mathrm{Ni}^{0}$ was found in the XRD pattern of the spent catalyst indicating a small amount of $\mathrm{S}^{2-}$ reacting on the catalyst surface (Fig. S22 in the $\mathrm{ESI}^{\dagger}$ ), which however does not influence the catalyst performance, as proven by SEC and monomers yield. In addition, FTIR analysis of SHF samples showed a decrease of the $\mathrm{O}=\mathrm{S}=\mathrm{O}$ stretching bands at $1036 \mathrm{~cm}^{-1}$ and at around $1200 \mathrm{~cm}^{-1}$, when compared to the original FTIR spectrum of LS, viz. Fig. S9 and Table S1 in the ESI. $\dagger$ Moreover, FTIR showed that the C-H stretching modes at 2954 and $2937 \mathrm{~cm}^{-1}$ exhibited a higher peak intensity in SHF samples than in the original LS. This suggests a higher concentration of alkyl chains in the SHF sample due to the LS hydrogenolysis/ hydrogenation.

In order to evaluate the depolymerization efficiency at different temperatures, the SHF product has been qualitatively and quantitatively analyzed using GC-MS and GC-FID, respectively. By GC-MS it was possible to identify a wide range of monomers (18 compounds), as reported in Table S5 in the ESI. $\dagger$ Among the identified compounds, 4-propyl guaiacol (G1), 4-ethyl guaiacol (G2), homovanillyl alcohol (G3), dihydroconyferyl alcohol (G4), guaiacol (G5), creosol (G6), and 4-propyl phenol (H1) were the predominant ones and have been quantified from GC-FID chromatograms (Table 2, and Fig. S13 and S22 in the ESI $\dagger$ ). Interestingly, the compounds with unsaturated alkene tails, i.e., eugenol (G7) and isoeugenol (G8), viz. Fig. S14 in the ESI, $\dagger$ were found only in traces, indicating the efficient hydrogenation of the double bonds at the alkene tails using $35 \mathrm{Ni} / \mathrm{NDC}$. At a reaction temperature of $150{ }^{\circ} \mathrm{C}$, the cumulative monomers yield $\left(Y_{\mathrm{CM}}\right)$ was found to be $9.1 \mathrm{mg} \mathrm{g}_{\mathrm{LS}}{ }^{-1}, 1.7 \mathrm{mg} \mathrm{g}_{\mathrm{LS}}{ }^{-1}$ and $0.1 \mathrm{mg} \mathrm{g}_{\mathrm{LS}}{ }^{-1}$ with $\mathrm{MeOH} / \mathrm{H}_{2} \mathrm{O}$, EtOH$/ \mathrm{H}_{2} \mathrm{O}$ and $\mathrm{H}_{2} \mathrm{O}$ as the solvent, respectively (Fig. 5, Table 2, and Fig. S24 and S25 in the ESI†). These compounds have boiling points between $200{ }^{\circ} \mathrm{C}$ and $300{ }^{\circ} \mathrm{C}$, which allows them to be separated from the product mixture for further chemocatalytic upgrading. $^{28,83}$ Alternatively, separation based on solvent extraction can be performed..$^{28,63,83,84}$ Once separated, the monomer can be valorised toward phenols and alkenes via hydroprocessing and dealkylation, while the oligomers can be used for materials applications. ${ }^{23,63}$

Increasing the temperature from $150{ }^{\circ} \mathrm{C}$ to $200{ }^{\circ} \mathrm{C}$ and $250{ }^{\circ} \mathrm{C}$ corresponded to an increase in the $Y_{\mathrm{CM}}$ from $9.1 \mathrm{mg}$ $\mathrm{g}_{\mathrm{LS}}{ }^{-1}$ to $16 \mathrm{mg} \mathrm{g}_{\mathrm{LS}}{ }^{-1}$ and to $34 \mathrm{mg} \mathrm{g}_{\mathrm{LS}}{ }^{-1}$ for SHF-MeOH/ $\mathrm{H}_{2} \mathrm{O}$ mixtures and from $1.7 \mathrm{mg} \mathrm{g}_{\mathrm{LS}}{ }^{-1}$ to $6.3 \mathrm{mg} \mathrm{g}_{\mathrm{LS}}{ }^{-1}$ and to $31 \mathrm{mg}$ $\mathrm{g}_{\mathrm{LS}}{ }^{-1}$ for SHF-EtOH/ $\mathrm{H}_{2} \mathrm{O}$, which correspond to the space-time cumulative monomer yield $\left(\mathrm{STY}_{\mathrm{CM}}\right)$ of $1.6,2.7$, and $5.8 \mathrm{mg} \mathrm{h}^{-1}$ $\mathrm{g}_{\mathrm{Ni}}{ }^{-1}$ for $\mathrm{MeOH} / \mathrm{H}_{2} \mathrm{O}$ and $0.29,1.1$, and $5.3 \mathrm{mg} \mathrm{h}^{-1} \mathrm{~g}_{\mathrm{Ni}}{ }^{-1}$ for EtOH/ $\mathrm{H}_{2} \mathrm{O}$. In contrast, $\mathrm{SHF}-\mathrm{H}_{2} \mathrm{O}$ exhibited a minimal $Y_{\mathrm{CM}}$ increase from $0.1 \mathrm{mg} \mathrm{g}_{\mathrm{LS}}{ }^{-1}$ to $0.7 \mathrm{mg} \mathrm{g}_{\mathrm{LS}}{ }^{-1}$ and to $1.7 \mathrm{mg} \mathrm{g}_{\mathrm{LS}}{ }^{-1}$

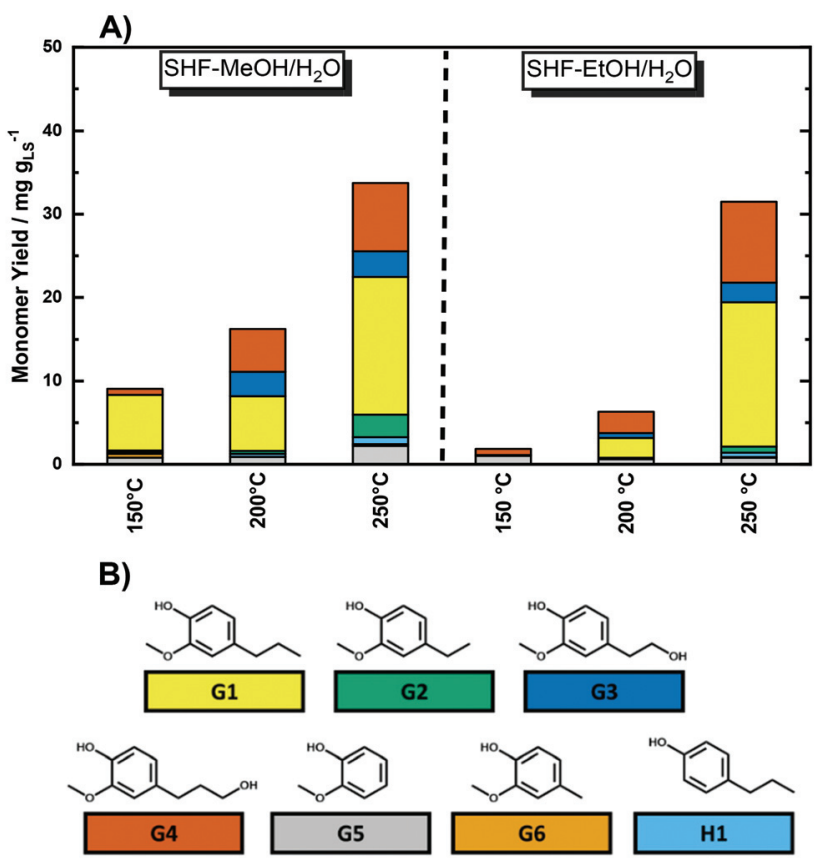

Fig. 5 (A) Monomer yield for the SHF-MeOH/H $\mathrm{H}_{2} \mathrm{O}$ and SHF-EtOH/ $\mathrm{H}_{2} \mathrm{O}$ as a function of temperature; reaction conditions: $c_{\mathrm{LS}}=1.0 \mathrm{wt} \%, T=$ $150{ }^{\circ} \mathrm{C}, 200{ }^{\circ} \mathrm{C}$ and $250^{\circ} \mathrm{C}, p=7.0 \mathrm{MPa}, Q_{\text {educt }}=1.0 \mathrm{~cm}^{3} \mathrm{~min}^{-1}, Q_{\mathrm{H}_{2}}=$ $20 \mathrm{~cm}^{3} \mathrm{~min}^{-1}, m_{35 \mathrm{Ni} / \mathrm{NDC}}=10 \mathrm{~g}, t_{\text {residence }}=50 \mathrm{~min}$, and weight hour space velocity (WHSV) $=0.17 \mathrm{gLs} \mathrm{h}^{-1} \mathrm{gNi}^{-1}$. (B) Structure of the quantified monomers.

at $150{ }^{\circ} \mathrm{C}, 200{ }^{\circ} \mathrm{C}$, and $250{ }^{\circ} \mathrm{C}$, respectively, viz. Fig. S25 in the ESI. $\dagger$ This lower $Y_{\mathrm{CM}}$ using pure $\mathrm{H}_{2} \mathrm{O}$ instead of the water/ alcohol mixture is in agreement with the previous study conducted with lignin ${ }^{77,82}$ In this context, low $Y_{\mathrm{CM}}$ is attributed to the poor solubility of the formed monomers in water, which lead to their adsorption on the catalyst surface, which subsequently led to low $Y_{\mathrm{CM}}$ with respect to the water/alcohol solvent mixture. ${ }^{82}$ Moreover, the hydrogenation of phenols in pure $\mathrm{H}_{2} \mathrm{O}$ can lead to over-hydrogenation toward hexanols. ${ }^{85}$ This is confirmed by the presence of only four monomers among the previously identified compounds, i.e. G2, G3 G5, and $\mathbf{H}$, viz. Fig. S25 in the ESI. $\dagger$ The low $Y_{\mathrm{CM}}$ combined with the high $M_{\mathrm{w}}$ of the SHF- $\mathrm{H}_{2} \mathrm{O}$ experiment indicates the necessity of using the water/alcohol mixture. In all the cases using alcohol/water mixtures, except EtOH/ $\mathrm{H}_{2} \mathrm{O}$ at $150{ }^{\circ} \mathrm{C}$, the monomers were similarly distributed with 4-propyl guaiacol (G1) and dihydroconyferyl alcohol (G4) as the major products, viz. Fig. 5. However, the dominant distribution of phenolic monomers with reduced tail, such as G1-G6 and H1, indicates the effective hydrogenolysis/hydrogenation of LS fragments in the SHF process by the $35 \mathrm{Ni} / \mathrm{NDC}$ catalyst. Nevertheless, it is important to underline that the selected compounds do not represent the entire amount of phenolic monomers, and for this reason, the cumulative monomer yield remains under-estimated. The values of monomer yield in both water/alcohol solvent systems at low temperature, i.e., at $150{ }^{\circ} \mathrm{C}$ and $200{ }^{\circ} \mathrm{C}$, are in-line with the maximum theoretical yield $\left(\sim 10 \mathrm{mg} \mathrm{g}_{\mathrm{LS}}{ }^{-1}\right)$ 
that Rinaldi et al. reported only for the $\beta-\mathrm{O}-4$ linkages of LS, indicating the cleavage of these linkage types. ${ }^{30}$ However, at $250{ }^{\circ} \mathrm{C}$, the cumulative monomer yield was found to be three times higher than the maximum theoretical yield, indicating the cleavage of other linkages in addition to $\beta-\mathrm{O}-4$. These observations indicate that at $150{ }^{\circ} \mathrm{C}$ and $200{ }^{\circ} \mathrm{C}$, depolymerization occurs mostly via hydrogenolysis of ether bonds. Whereas at $250{ }^{\circ} \mathrm{C}$, in addition to $\beta-\mathrm{O}-4$, a wide number of linkages, e.g., 4-O-5 and 5-5 bonds, are cleaved solvothermally followed by the stabilization of the unsaturated bonds, viz in Fig. S26 in the ESI. $\dagger$ This process is within the typical lignin fragmentation at high temperatures $\left(250-400{ }^{\circ} \mathrm{C}\right) .{ }^{79,86}$ The solvothermal cleavage of bonds produces unstable intermediates, such as radicals and double bonds, which are hydrogenated using $35 \mathrm{Ni} / \mathrm{NDC}$, viz. Fig. S26 in the ESI. $\dagger$ This proposed scheme would confirm the protective action against recondensation of the $35 \mathrm{Ni} / \mathrm{NDC}$ catalyst. For the catalytic hydrogenolysis of $\beta-\mathrm{O}-$ 4 and 4-Ov5 ether bonds, we proposed that these steps are following a classical hydrogenation mechanism. This mechanism based on dissociative $\mathrm{H}_{2}$ adsorption on $\mathrm{Ni}$ followed by LS adsorption and bond cleavage, is analogous to those of studies in the literature conducted with model compounds, viz Fig. S27. $\dagger^{87-89}$

In the studied system, the SHF-MeOH/ $\mathrm{H}_{2} \mathrm{O}$ solvent mixture showed a higher monomer yield over all temperature ranges than SHF-EtOH/ $/ \mathrm{H}_{2} \mathrm{O}$. The higher activity of $\mathrm{MeOH} /$ $\mathrm{H}_{2} \mathrm{O}$ confirms the results of the LS experiments and is attributed to the high polarity of this mixture that allows better solubility of LS, which led to high diffusion of LS through the 35Ni/NDC catalyst and higher LS hydrogenolysis/hydrogenation rates. These findings are in strong agreement with other studies conducted with $\mathrm{MeOH}$ on catalytic lignin depolymerization reported by the Sels group. ${ }^{76,90}$ This demonstrated the crucial role of a polar solvent in lignin solubilization which could lead to improved process efficiency. Therefore, $\mathrm{MeOH} / \mathrm{H}_{2} \mathrm{O}$ has been selected for further investigations as the solvent mixture, due to its higher $Y_{\mathrm{CM}}$ when compared to EtOH/ $\mathrm{H}_{2} \mathrm{O}$ or pure $\mathrm{H}_{2} \mathrm{O}$.

\section{Process optimization}

In order to maximize the efficiency of LS depolymerization toward monomers, an experiment has been performed with a higher LS concentration (2.5 wt $\%$ ) than in previous SF and SHF $(1.0 \mathrm{wt} \%)$ experiments at $250{ }^{\circ} \mathrm{C}$. It is important to mention that $2.5 \mathrm{wt} \%$ was chosen as the highest concen- tration, i.e., it is the highest limit of LS solubility in the used solvent mixture $\left(\mathrm{MeOH} / \mathrm{H}_{2} \mathrm{O}\right)$ at room temperature.

In terms of weight hourly space velocity (WHSV), increasing the concentration from 1 to $2.5 \mathrm{wt} \%$ corresponded to an increase from 0.17 to $0.43 \mathrm{~g}_{\mathrm{LS}} \mathrm{h}^{-1} \mathrm{~g}_{\mathrm{Ni}}{ }^{-1}$. Herein, $M_{\mathrm{w}}$ and $M_{\mathrm{n}}$ of 430 and $391 \mathrm{~g} \mathrm{~mol}^{-1}$ with $Ð$ of 1.1 , respectively, were found (see Table 3). These values are comparable to the one obtained from the experiment conducted using $1.0 \mathrm{wt} \% \mathrm{LS}$ solution (Table 3). Also, the cumulative monomer yield was found to be similar in both cases. These results show no significant influence of the higher concentration (from $1.0 \mathrm{wt} \%$ to $2.5 \mathrm{wt} \%$ ) of LS on the catalyst performance. Accordingly, increasing the concentration from 1 to $2.5 \mathrm{wt} \%$ corresponded to an increase of $\mathrm{STY}_{\mathrm{CM}}$ from 5.8 to $14 \mathrm{mg} \mathrm{h} \mathrm{h}^{-1} \mathrm{~g}_{\mathrm{Ni}}{ }^{-1}$. Because of the higher weight productivity, the $2.5 \mathrm{wt} \%$ concentration was selected to investigate the catalyst stability over time on stream (TOS), viz. Fig. S28 in the ESI. $\dagger$ Exposing the $35 \mathrm{Ni} / \mathrm{NDC}$ catalyst to the reaction conditions for $9 \mathrm{~h}$, did not affect the $Y_{\mathrm{CM}}$, which was found to be constant ( $c a$. $30 \mathrm{mg} \mathrm{g}_{\mathrm{LS}}{ }^{-1}$ ). However, the $\mathrm{N}_{2}$ physisorption of $35 \mathrm{Ni}$ / NDC-TOS exhibited a loss in specific surface area from 578 to $272 \mathrm{~m}^{2} \mathrm{~g}^{-1}$ (Fig. S29 in the ESI $\dagger$ ). This decrease in the surface area indicates product deposition onto the catalysts, due to the affinity between aromatics and porous carbon, which is in agreement with a similar study conducted by our group for vanillin hydrogenation. ${ }^{68}$ The XRD diffraction patterns of the spent catalyst after $9 \mathrm{~h}$ of TOS (35Ni/NDC-TOS) showed similar peaks to those of the spent catalyst after $1 \mathrm{~h}$ (Fig. S22 in the ESI $\dagger$ ), with mainly $\mathrm{Ni}^{0}$ reflections and the presence of $\mathrm{Ni}(\mathrm{OH})_{2}$ and $\mathrm{Ni}_{3} \mathrm{~S}_{2}$ phases. This remarkable resistance of $\mathrm{Ni}^{0}$ for such a long time under harsh conditions $\left(250{ }^{\circ} \mathrm{C}\right.$ and the presence of $\mathrm{S}$ ), is attributed to the establishment of a Mott-Schottky stabilization effect between the $\mathrm{Ni}^{0}$ and the $\mathrm{N}$ of the carbon support. ${ }^{68,91,92}$

One of the advantages of operating in continuous flow systems is the possibility to couple multiple reactors together. ${ }^{67}$ Herein, two identical packed reactors with $35 \mathrm{Ni}$ / NDC have been coupled in series, in order to prolong the contact time between the LS solution and the catalyst and consequently optimize the monomer yield (Fig. 6 and Fig. S5 in the ESI $\dagger$ ). Moreover, coupling two flow reactors in series aims to mimic an industrial scale up of such process. Therein, the concentrated $2.5 \mathrm{wt} \%$ LS solution has been continuously fed through two coupled reactors packed with 35Ni/NDC. Accordingly, the double amount of the catalyst is used, result-

Table 3 SHF experiments using the $\mathrm{MeOH} / \mathrm{H}_{2} \mathrm{O}$ solvent mixture

\begin{tabular}{llllll}
\hline Sample & $M_{\mathrm{w}}{ }^{a} / \mathrm{g} \mathrm{mol}^{-1}$ & $M_{\mathrm{n}}{ }^{a} / \mathrm{g} \mathrm{mol}^{-1}$ & $D^{a} /-$ & $Y_{\mathrm{CM}}{ }^{b} / \mathrm{mg} \mathrm{g}_{\mathrm{LS}}{ }^{-1}$ & $\mathrm{STY}_{\mathrm{CM}}{ }^{b} / \mathrm{mg} \mathrm{h}^{-1} \mathrm{~g}_{\mathrm{Ni}}{ }^{-1}$ \\
\hline LS & 12390 & 1364 & 9.1 & n.a. & n.a \\
SHF-MeOH/H $\mathrm{H}_{2} \mathrm{O}$ & 433 & 360 & 1.2 & 34 & 5.8 \\
Flow 2.5 wt\% & 430 & 391 & 1.1 & 33 & 14 \\
Dual column & 393 & 337 & 1.1 & 42 & 9.0 \\
Batch 1 h & 1615 & 491 & 3.3 & 19 & n.a. \\
Batch 3 h & 6942 & 684 & 10 & n.d. & n.a
\end{tabular}

n.a. $=$ not applicable. ${ }^{a}$ Calculated by SEC. ${ }^{b}$ Calculated from GC-FID results. ${ }^{c}$ Not determined as the $M_{\mathrm{w}}$ is high with respect to $1 \mathrm{~h}$. 

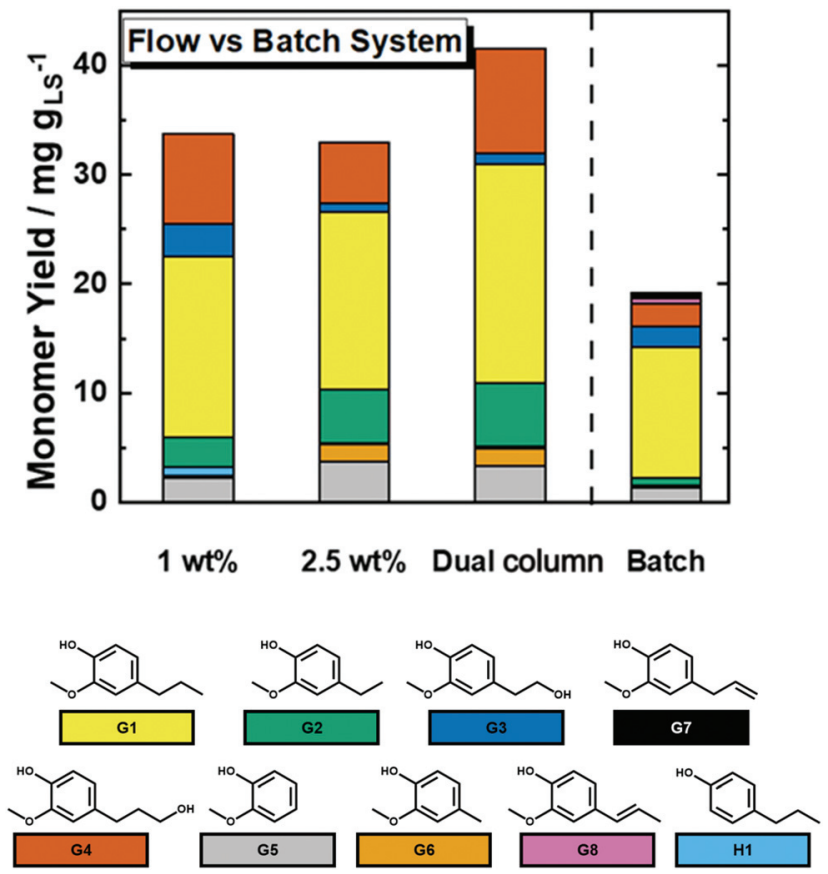

Fig. 6 Monomers yield derived from the SHF- MeOH/ $\mathrm{H}_{2} \mathrm{O}$ in the continuous flow system with one and dual reactors and in a batch reactor. Continuous flow system with one tubular reactor; reaction conditions: $C_{\mathrm{LS}}=1.0$ and $2.5 \mathrm{wt} \%, T=250^{\circ} \mathrm{C}, p=7.0 \mathrm{MPa}, Q_{\text {educt }}=1.0 \mathrm{~cm}^{3} \mathrm{~min}^{-1}$, $Q_{\mathrm{H}_{2}}=20 \mathrm{~cm}^{3} \mathrm{~min}^{-1}, m_{35 \mathrm{Ni} / \mathrm{NDC}}=10 \mathrm{~g}, t_{\text {residence }}=50 \mathrm{~min}$, and weight hour space velocity (WHSV) $=0.17$ and $0.43 \mathrm{gLS}^{-1} \mathrm{~g} \mathrm{Ni}^{-1}$. Dual column continuous flow system; reaction conditions: $C_{\mathrm{LS}}=2.5 \mathrm{wt} \%, T_{1}$ and $T_{2}=$ $250^{\circ} \mathrm{C}, p_{\text {system }}=7.0 \mathrm{MPa}, Q_{\text {educt }}=1.0 \mathrm{~cm}^{3} \mathrm{~min}^{-1}, Q_{\mathrm{H}_{2}}=20 \mathrm{~cm}^{3} \mathrm{~min}^{-1}$, $m_{35 \mathrm{Ni} / \mathrm{NDC}}$ in $R_{1}$ and $R_{2}=10 \mathrm{~g}, t_{\text {residence }}=100 \mathrm{~min}$, and weight hour space velocity (WHSV) $=0.21 \mathrm{gLS} \mathrm{h}^{-1} \mathrm{gNi}^{-1}$. Batch system; reaction conditions: $c_{\mathrm{LS}}=2.5 \mathrm{wt} \%, V_{\text {educt }}=30 \mathrm{~cm}^{3}, T=250^{\circ} \mathrm{C}, p_{\mathrm{H}_{2}}=7.0 \mathrm{MPa}, n=$ $400 \mathrm{rpm}, m_{35 \mathrm{~N} / \mathrm{NDC}}=1 \mathrm{~g}$ and $t_{\text {reaction }}=60 \mathrm{~min}$.

ing in two-times lower WHSV (from 0.43 to $0.21 \mathrm{~g}_{\mathrm{LS}} \mathrm{h}^{-1} \mathrm{~g}_{\mathrm{Ni}}{ }^{-1}$ ). The molecular weight distributions in this experiment showed a slight decrease when compared with the sole reactor experiment using $2.5 \mathrm{wt} \%$ (Table 3). In contrast, the cumulative monomer yield increased from 33 to $42 \mathrm{mg} \mathrm{g}_{\mathrm{LS}}{ }^{-1}$ when compared to the single column experiment (Fig. 6 and Table 2), i.e. prolonging the residence time resulted in an improved monomer yield. In addition, this monomer yield (42 $\mathrm{mg} \mathrm{g}_{\mathrm{LS}}{ }^{-1}$ ) is four times higher than the maximum theoretical monomer yield $\left(\sim 10 \mathrm{mg} \mathrm{g}_{\mathrm{LS}}{ }^{-1}\right)$ reported by Rinaldi et al. based on the cleavage of $\beta-\mathrm{O}-4$ linkages in $\mathrm{LS}^{30}$ However, the benefits of using two columns in terms of $Y_{\mathrm{CM}}$ are combined with STY decreasing from 14 to $9.0 \mathrm{mg} \mathrm{h}^{-1} \mathrm{~g}_{\mathrm{Ni}}{ }^{-1}$, viz. Table 3 . This indicates that an excess amount of the catalyst is used in the dual columns experiment, with a non-optimized WHSV.

\section{Comparison between batch and flow}

To identify the assumed advantages of continuous flow over batch systems, catalytic LS depolymerization was performed in a batch system using the $\mathrm{MeOH} / \mathrm{H}_{2} \mathrm{O}$ solvent system. $1 \mathrm{~h}$ reaction time has been set to be comparable to the one in the flow system, yielding a $M_{\mathrm{w}}$ of $1615 \mathrm{~g} \mathrm{~mol}^{-1}$ and a $\doteq$ of 3.3 (Table 3).
These values are considerably higher than the ones in the flow system experiment. In addition, the cumulative monomer yield was found to be $19 \mathrm{mg} \mathrm{g}_{\mathrm{LS}}{ }^{-1}$, which is lower than that for the continuous flow system $\left(33 \mathrm{mg} \mathrm{g}_{\mathrm{LS}}{ }^{-1}\right.$ using $2.5 \mathrm{wt} \%$ LS solution), viz. Fig. 6 and Table 2. Interestingly, the batch systems showed the presence of monomer with an unsaturated alkene tail, i.e., eugenol and isoeugenol, which could be a sign of the beginning of catalyst deactivation. Moreover, increasing the reaction time from $1 \mathrm{~h}$ to $3 \mathrm{~h}$, corresponded to an increase of $M_{\mathrm{w}}$ from $1615 \mathrm{~g} \mathrm{~mol}^{-1}$ to $6942 \mathrm{~g} \mathrm{~mol}^{-1}$ as a result of catalyst deactivation, combined with an increase of $D$ from 3.3 to 10 . These findings are attributed to the fragment re-polymerization in a batch system that also leads to catalyst deactivation due to longer contact times between reactants and products. ${ }^{93}$

\section{Conclusions}

Industrial sodium lignosulfonate (LS) was successfully valorized using solvothermal fragmentation independently and combined with catalytic hydrogenolysis/hydrogenation in continuous flow systems. The depolymerization was found to occur thermally in the absence of the catalyst, rather independent of the solvent mixture. The decrease of molecular weight has been found to depend on the reaction temperature, i.e., LS at those temperatures is an unstable polymer and shows ceiling behaviour. This allows direct and simple tuning of molecular weights of the formed fractions based on reaction temperatures. To obtain monomers and lower molecular weight fractions, the solvothermal fragmentation should be coupled with a catalytic hydrogenolysis/hydrogenation step. An optimum cumulative monomer yield of $34 \mathrm{mg} \mathrm{g}_{\mathrm{LS}}{ }^{-1}$ (STY of $5.8 \mathrm{mg} \mathrm{h}^{-1} \mathrm{~g}_{\mathrm{Ni}}{ }^{-1}$ ) has been found at $250{ }^{\circ} \mathrm{C}$ using $\mathrm{MeOH} / \mathrm{H}_{2} \mathrm{O}$ as a solvent, while indeed most of the fragments are in the dimer and trimer range, which is more exciting from a polymer perspective. Moreover, the presence of a hydrogenation catalyst allowed a higher degree of depolymerization even at a lower temperature. This clearly showed that $35 \mathrm{Ni}$ / NDC plays a vital role in this approach, as it is responsible for further fragmentation through hydrogenolysis/hydrogenation steps.

Extending the residence time by coupling two reactors yielded an even higher cumulative monomer yield of $42 \mathrm{mg}$ $\mathrm{g}_{\mathrm{LS}}{ }^{-1}$ with respect to the experiment in a single tubular reactor. However, the decreased STY of this approach $(9.0 \mathrm{mg}$ $\mathrm{h}^{-1} \mathrm{~g}_{\mathrm{Ni}}{ }^{-1}$ ) pointed out the need for higher weight productivity in view of further possible improvements.

The obtained monomer yield is relatively low, but also expected and well-known for technical lignin. ${ }^{30}$ This is due to the high sulfonate (and counter-ion) content, as well as the low amount of $\mathrm{C}-\mathrm{O}$ bonds of $\mathrm{LS}$ when compared to native lignin. ${ }^{30}$ This is the intrinsic limitation of using technical lignin as the starting feedstock for lignin depolymerization. Nevertheless, in our contribution, we reported on a high cumulative monomer yield when it is compared to other work presented in the literature using similar lignin. ${ }^{52,53}$ 
In addition to the monomers, the SHF process simultaneously produces lignin oligomers, which can be also applied in a wide range of applications. Based on this, we believe that our approach has the potential to use both the monomer and the oligomers fractions, moreover the weight of the product solutions can be tuned according to the temperature.

We also have to underline that all these data were obtained using an industrial LS waste, i.e., containing $7.0 \mathrm{wt} \%$ sulfur and 10 wt $\%$ sodium, rather than impurity-free lignin. Certainly, other lignin types could allow high targeted monomer yields. Nevertheless, giving value to industrial waste will increase the sustainability of already established biorefinery processes and accelerate the transition toward a sustainable circular bio-economy.

\section{Conflicts of interest}

The authors declare that they have no known competing financial interests or personal relationships that could have appeared to influence the work reported in this paper.

\section{Acknowledgements}

The authors are grateful to the Max Planck Society for the financial support. Paolo Giusto, Aleksander Savateev, Alessandro Vincenzo Cataldo, Enrico Lepre and Jose Alirio Mendoza Mesa are greatly acknowledged for scientific discussion, feedback, assistance and suggestions. The authors are grateful to Irina Shekova for the support in catalyst synthesis. Jessica Brandt, Antje Völkel, Marlies Gräwert and Bolortuya Badamdorj from the Max Planck Institute of Colloids and Interfaces are acknowledged for ICP, EA, SEC and EDS analyses, respectively. Thanks are also extended to Klaus Bienert, Michael Born, Marco Bott and Tobias Schmidt from the electrical and mechanical workshop at the Max Planck Institute of Colloids and Interfaces. Joris Snaet is greatly acknowledged for the design of the cover artwork image. Open Access funding was provided by the Max Planck Society.

\section{References}

1 A. Katelhon, R. Meys, S. Deutz, S. Suh and A. Bardow, Proc. Natl. Acad. Sci. U. S. A., 2019, 116, 11187-11194.

2 M. Al-Naji, J. Van Aelst, Y. Liao, M. d'Hullian, Z. Tian, C. Wang, R. Gläser and B. F. Sels, Green Chem., 2020, 22, 1171-1181.

3 M. Al-Naji, A. Yepez, A. M. Balu, A. A. Romero, Z. Chen, N. Wilde, H. Li, K. Shih, R. Gläser and R. Luque, J. Mol. Catal. A: Chem., 2016, 417, 145-152.

4 M. Al-Naji, M. Popova, Z. Chen, N. Wilde and R. Gläser, ACS Sustainable Chem. Eng., 2019, 8, 393-402.
5 C. O. Tuck, E. Pérez, I. T. Horváth, R. A. Sheldon and M. Poliakoff, Science, 2012, 337, 695-699.

6 R. A. Sheldon, ACS Sustainable Chem. Eng., 2017, 6, 32-48.

7 S. Pacala and R. Socolow, Science, 2004, 305, 968-972.

8 B. Kumru, J. A. Mendoza Mesa, M. Antonietti and M. AlNaji, ACS Sustainable Chem. Eng., 2019, 7, 17574-17579.

9 M. Al-Naji, H. Schlaad and M. Antonietti, Macromol. Rapid Commun., 2020, 2000485, DOI: 10.1002/marc.202000485.

10 J. A. Mendoza Mesa, F. Brandi, I. Shekova, M. Antonietti and M. Al-Naji, Green Chem., 2020, 22, 7398-7405.

11 P. Anastas and N. Eghbali, Chem. Soc. Rev., 2010, 39, 301312.

12 M. M. Abu-Omar, K. Barta, G. T. Beckham, J. Luterbacher, J. Ralph, R. Rinaldi, Y. Roman-Leshkov, J. Samec, B. Sels and F. Wang, Energy Environ. Sci., 2021, 14, 262-292.

13 A. Corma, S. Iborra and A. Velty, Chem. Rev., 2007, 107, 2411-2502.

14 M. Besson, P. Gallezot and C. Pinel, Chem. Rev., 2014, 114, 1827-1870.

15 F. H. Isikgor and C. R. Becer, Polym. Chem., 2015, 6, 44974559.

16 D. Esposito and M. Antonietti, Chem. Soc. Rev., 2015, 44, 5821-5835.

17 J. Martin and M. Haggith, Enviromental Paper Network: The State of Global Paper Industry https:/www.environmentalpaper.org, (accessed 27 January 2021).

18 C. E. Wyman, B. E. Dale, R. T. Elander, M. Holtzapple, M. R. Ladisch and Y. Lee, Bioresour. Technol., 2005, 96, 1959-1966.

19 A. J. Ragauskas, G. T. Beckham, M. J. Biddy, R. Chandra, F. Chen, M. F. Davis, B. H. Davison, R. A. Dixon, P. Gilna, M. Keller, P. Langan, A. K. Naskar, J. N. Saddler, T. J. Tschaplinski, G. A. Tuskan and C. E. Wyman, Science, 2014, 344, 1246843-1246843.

20 H. Sadeghifar and A. Ragauskas, ACS Sustainable Chem. Eng., 2020, 8, 8086-8101.

21 T. Aro and P. Fatehi, ChemSusChem, 2017, 10, 1861-1877.

22 P. C. A. Bruijnincx, R. Rinaldi and B. M. Weckhuysen, Green Chem., 2015, 17, 4860-4861.

23 Y. Liao, S.-F. Koelewijn, G. Van den Bossche, J. Van Aelst, S. Van den Bosch, T. Renders, K. Navare, T. Nicolaï, K. Van Aelst, M. Maesen and B. Sels, Science, 2020, 367, 13851390.

24 E. Paone, T. Tabanelli and F. Mauriello, Curr. Opin. Green Sustainable Chem., 2020, 24, 1-6.

25 S. S. Hassan, G. A. Williams and A. K. Jaiswal, Renewable Sustainable Energy Rev., 2019, 101, 590-599.

26 P. C. Bruijnincx, R. Rinaldi and B. M. Weckhuysen, Green Chem., 2015, 17, 4860-4861.

27 Z. Sun, B. Fridrich, A. de Santi, S. Elangovan and K. Barta, Chem. Rev., 2018, 118, 614-678.

28 W. Schutyser, T. Renders, S. Van den Bosch, S. F. Koelewijn, G. T. Beckham and B. F. Sels, Chem. Soc. Rev., 2018, 47, 852-908.

29 J. E. Holladay, J. F. White, J. J. Bozell and D. Johnson, Top value-added chemicals from biomass-Volume II-Results of 
screening for potential candidates from biorefinery lignin, Pacific Northwest National Lab.(PNNL), Richland, WA (United States), 2007.

30 R. Rinaldi, R. Jastrzebski, M. T. Clough, J. Ralph, M. Kennema, P. C. A. Bruijnincx and B. M. Weckhuysen, Angew. Chem., Int. Ed., 2016, 55, 8164-8215.

31 J. Zakzeski, P. C. Bruijnincx, A. L. Jongerius and B. M. Weckhuysen, Chem. Rev., 2010, 110, 3552-3599.

32 H. Kobayashi, H. Ohta and A. Fukuoka, in Catalytic Hydrogenation for Biomass Valorization, ed. R. Rinaldi, RCS Energy and Environment Series No. 13, 2015, pp. 52-71.

33 A. Llevot, P. K. Dannecker, M. von Czapiewski, L. C. Over, Z. Soyler and M. A. Meier, Chem. - Eur. J., 2016, 22, 1151011521.

34 A. Llevot, E. Grau, S. Carlotti, S. Grelier and H. Cramail, Macromol. Rapid. Commun., 2016, 37, 9-28.

35 Z. Strassberger, S. Tanase and G. Rothenberg, RSC Adv., 2014, 4, 25310-25318.

36 S. Laurichesse and L. Avérous, Prog. Polym. Sci., 2014, 39, 1266-1290.

37 Z. Sun, J. Cheng, D. Wang, T. Q. Yuan, G. Song and K. Barta, ChemSusChem, 2020, 13(19), 5199-5212.

38 I. F. Demuner, J. L. Colodette, A. J. Demuner and C. M. Jardim, Bioresour. Technol., 2019, 14(3), 75437581.

39 J. Ruwoldt, Surfaces, 2020, 3, 622-648.

40 P. Fatehi and Y. Ni, in Sustainable Production of Fuels, Chemicals, and Fibers from Forest Biomass, ed. B. Zhu, ACS Symposium Series; American Chemical Society, Washington, DC, 2011.

41 M. Y. A. Mollah, W. Yu, R. Schennach and D. L. Cocke, Cem. Concr. Res., 2000, 267-273, DOI: 10.1016/S00088846(99)00243-4.

42 L. Hu, Y. Zhou, M. Zhang and R. Liu, BioResources, 2012, 7, 554-564.

43 Borregaard, Potential applications for different lignin sources based on experience from Borregaard, https://www. google.com/url? sa=t\&rct=j\&q=\&esrc $=$ s\&source=web\&cd= \&ved=2ahUKEwit0eSf7KruAhURahQKHRtFCFoQFjAAeg QIBxAC\&url=http\%3A\%2F\%2Fwww.lth.se\%2Ffileadmin \% 2Fenergiportalen\%2FEnergy_Portal\%2FFiles\%2FPres_ Rodsrud.pdf\&usg=AOvVaw2jH3uyvQBINJ-PiQySZp9l, (accessed 27 January 2021).

44 Y. Qin, D. Yang and X. Qiu, ACS Sustainable Chem. Eng., 2015, 3, 3239-3244.

45 S. Gao, Z. Cheng, X. Zhou, Y. Liu, R. Chen, J. Wang, C. Wang, F. Chu, F. $\mathrm{Xu}$ and D. Zhang, Int. J. Biol. Macromol., 2020, 161, 755-762.

46 B. V. K. J. Schmidt, V. Molinari, D. Esposito, K. Tauer and M. Antonietti, Polymer, 2017, 112, 418-426.

47 C. Che, M. Vagin, U. Ail, V. Gueskine, J. Phopase, R. Brooke, R. Gabrielsson, M. P. Jonsson, W. C. Mak, M. Berggren and X. Crispin, Adv. Sustainable Syst., 2019, 3, 1900039.

48 R. Guterman, V. Molinari and E. Josef, Angew. Chem., Int. Ed., 2019, 58, 13044-13050.
49 X. Zhang, A. L. Licon, T. I. Harris, P. F. Oliveira, B. J. McFarland, B. E. Taurone, B. J. Walsh, B. E. Bell, C. T. Walker, R. V. Lewis and J. A. Jones, ACS Omega, 2019, 4, 4832-4838.

50 J. Pang, W. Zhang, H. Zhang, J. Zhang, H. Zhang, G. Cao, M. Han and Y. Yang, Carbon, 2018, 132, 280-293.

51 V. Molinari and M. Antonietti, Lignin-based composite materials and methods for its preparation, European patent office Patent No EP 3266810 A1, 2018.

52 J. Horáček, J.-P. Mikkola, A. Samikannu, G. Št’ávová, W. Larsson, L. Hora and D. Kubička, Top. Catal., 2013, 56, 794-799.

53 R. Shu, Y. Xu, L. Ma, Q. Zhang, T. Wang, P. Chen and Q. Wu, RSC Adv., 2016, 6, 88788-88796.

54 Q. Song, F. Wang and J. Xu, Chem. Commun., 2012, 48, 7019-7021.

55 P. Cui, H.-X. Fang, C. Qian and M.-H. Cheng, Chromatographia, 2019, 83, 87-93.

56 M. Fache, B. Boutevin and S. Caillol, ACS Sustainable Chem. Eng., 2015, 4, 35-46.

57 K. Van Aelst, E. Van Sinay, T. Vangeel, E. Cooreman, G. Van den Bossche, T. Renders, J. Van Aelst, S. Van den Bosch and B. F. Sels, Chem. Sci., 2020, 11, 11498-11508.

58 S. Van den Bosch, S. F. Koelewijn, T. Renders, G. Van den Bossche, T. Vangeel, W. Schutyser and B. Sels, in Lignin Chemistry, ed. L. Serrano, R. Luque and B. Sels, Springer Nature Switzerland, Cham, 2020, pp. 129-168.

59 T. Renders, G. Van den Bossche, T. Vangeel, K. Van Aelst and B. Sels, Curr. Opin. Biotechnol, 2019, 56, 193-201.

60 S. Van den Bosch, S. F. Koelewijn, T. Renders, G. Van den Bossche, T. Vangeel, W. Schutyser and B. F. Sels, in Topics Curr Chem, 2018, vol. 376.

61 T. Renders, S. Van den Bosch, S. F. Koelewijn, W. Schutyser and B. F. Sels, Energy Environ. Sci., 2017, 10, 1551-1557.

62 E. Cooreman, T. Vangeel, K. Van Aelst, J. Van Aelst, J. Lauwaert, J. W. Thybaut, S. Van den Bosch and B. F. Sels, Ind. Eng. Chem. Res., 2020, 59, 17035-17045.

63 Y. Liao, S. Van den Bosch, J. Van Aelst and B. Sels, Catalytic funneling of phenolics, US Patent No 17083154, 2021.

64 S. G. Parto, J. M. Christensen, L. S. Pedersen, A. B. Hansen, F. Tjosås, C. Spiga, C. D. Damsgaard, D. B. Larsen, J. Ø. Duus and A. D. Jensen, Energy Fuels, 2019, 33, 11961209.

65 S. Ghafarnejad Parto, J. Munkholt Christensen, L. Saaby Pedersen, F. Tjosås and A. D. Jensen, Catalysts, 2018, 8, 502.

66 M. L. Stone, E. M. Anderson, K. M. Meek, M. Reed, R. Katahira, F. Chen, R. A. Dixon, G. T. Beckham and Y. Román-Leshkov, ACS Sustainable Chem. Eng., 2018, 6, 11211-11218.

67 F. Brandi, I. Khalil, M. Antonietti and M. Al-Naji, ACS Sustainable Chem. Eng., 2021, 9, 927-935.

68 F. Brandi, M. Bäumel, V. Molinari, I. Shekova, I. Lauermann, T. Heil, M. Antonietti and M. Al-Naji, Green Chem., 2020, 22, 2755-2766. 
69 F. Brandi, M. Bäumel, I. Shekova, V. Molinari and M. AlNaji, Sustainable Chem., 2020, 1, 106-115.

70 M. Al-Naji, B. Puertolas, B. Kumru, D. Cruz, M. Baumel, B. Schmidt, N. V. Tarakina and J. Perez-Ramirez, ChemSusChem, 2019, 12(12), 2628-2636.

71 O. Musl, I. Sulaeva, M. Bacher, A. K. Mahler, T. Rosenau and A. Potthast, ChemSusChem, 2020, 13, 4595-4604.

72 B. F. Lutnaes, B. O. Myrvold, R. A. Lauten and M. M. Endeshaw, Magn. Reson. Chem., 2008, 46, 299-305.

73 M. Alonso, M. Oliet, F. Rodriguez, G. Astarloa and J. Echeverría, J. Appl. Polym. Sci., 2004, 94, 643-650.

74 K. Fukuhara, K. Nakajima, M. Kitano, S. Hayashi and M. Hara, Phys. Chem. Chem. Phys., 2013, 15, 9343-9350.

75 E. M. Anderson, M. L. Stone, R. Katahira, M. Reed, G. T. Beckham and Y. Román-Leshkov, Joule, 2017, 1, 613622.

76 W. Schutyser, S. Van den Bosch, T. Renders, T. De Boe, S. F. Koelewijn, A. Dewaele, T. Ennaert, O. Verkinderen, B. Goderis, C. M. Courtin and B. F. Sels, Green Chem., 2015, 17, 5035-5045.

77 T. Renders, S. Van den Bosch, T. Vangeel, T. Ennaert, S.-F. Koelewijn, G. Van den Bossche, C. M. Courtin, W. Schutyser and B. F. Sels, ACS Sustainable Chem. Eng., 2016, 4, 6894-6904.

78 X. Wang and R. Rinaldi, ChemSusChem, 2012, 5, 14551466.

79 T. Watanabe, H. Kawamoto and S. Saka, Holzforschung, 2009, 63, 424-430.

80 B. D. Mar, H. W. Qi, F. Liu and H. J. Kulik, J. Phys. Chem. A, 2015, 119, 6551-6562.
81 Y. M. Questell-Santiago, M. V. Galkin, K. Barta and J. S. Luterbacher, Nat. Rev. Chem., 2020, 4, 311-330.

82 T. Renders, E. Cooreman, S. Van den Bosch, W. Schutyser, S. F. Koelewijn, T. Vangeel, A. Deneyer, G. Van den Bossche, C. M. Courtin and B. F. Sels, Green Chem., 2018, 20, 4607-4619.

83 O. D. Mante, D. C. Dayton and M. Soukri, RSC Adv., 2016, 6, 94247-94255.

84 J. S. Kim, Bioresour. Technol., 2015, 178, 90-98.

85 J. He, C. Zhao and J. A. Lercher, J. Catal., 2014, 309, 362-375.

86 X. Zhou, L. J. Broadbelt and R. Vinu, in Thermochemical Process Engineering, 2016, pp. 95-198, DOI: 10.1016/bs. ache.2016.09.002.

87 Y. Li, S. D. Karlen, B. Demir, H. Kim, J. Luterbacher, J. A. Dumesic, S. S. Stahl and J. Ralph, ChemSusChem, 2020, 13, 4487-4494.

88 J. He, C. Zhao, D. Mei and J. A. Lercher, J. Catal., 2014, 309, 280-290.

89 J. He, C. Zhao and J. A. Lercher, J. Am. Chem. Soc., 2012, 134, 20768-20775.

90 J. H. Li, C. F. Lin, W. Qin, X. B. Xiao and L. Wei, Acta Phys. - Chim. Sin., 2016, 32, 2717-2723.

91 Z. H. Xue, J. T. Han, W. J. Feng, Q. Y. Yu, X. H. Li, M. Antonietti and J. S. Chen, Angew. Chem., Int. Ed., 2018, 57, 2697-2701.

92 X. H. Li and M. Antonietti, Chem. Soc. Rev., 2013, 42, 65936604.

93 S. M. G. Lama, J. Pampel, T.-P. Fellinger, V. P. Beškoski, L. Slavković-Beškoski, M. Antonietti and V. Molinari, ACS Sustainable Chem. Eng., 2017, 5, 2415-2420. 